\title{
TESTING THE CATASTROPHIC RECORDER RESISTANCE AGAINST THE IMPACT OF CATASTROPHIC FACTORS
}

\author{
BADANIA ODPORNOŚCI REJESTRATORA \\ KATASTROFICZNEGO NA ODDZIALYWANIE \\ CZYNNIKÓW KATASTROFY
}

\author{
Zbigniew Jakielaszek, Grzegorz Kowaleczko, \\ Andrzej J. Panas, Mirosław Nowakowski
}

Air Force Institute of Technology. Instytut Techniczny Wojsk Lotniczych

\begin{abstract}
The subject of the research was a catastrophic recorder of the S2-3a system for recording flight parameters, developed at the Air Force Institute of Technology. The article discusses tests of catastrophic recorders' resilience to factors present at aircraft accidents. The document specifying the requirements for catastrophic recorders of flight parameters includes the defence standard: NO-16A200, and the European standard: EuroCAE ED-112. According to NO-16-A200 and ED-112 standards, the protective unit should be resistant to: g-forces existing during crash, puncture, compression, fire, underwater pressure and aggressive liquids.
\end{abstract}

Keywords: catastrophic recorder, resistance tests

Streszczenie Przedmiotem badań byt rejestrator katastroficzny systemu rejestracji parametrów lotu S2-3a opracowany w Instytucie Technicznym Wojsk Lotniczych. $W$ artykule omówiono badania odporności rejestratora katastroficznego na oddziatywanie czynników katastrofy lotniczej. Dokumentem określajacym wymagania dla rejestratora katastroficznego jest norma obronna NO-16-A200 $i$ norma europejska EuroCAE ED-112. Wedtug normy NO-16-A200 i ED-112 rejestrator katastroficzny powinien być odporny na: przeciażenie wystęujace przy zderzeniu, przebicie, ściskanie statyczne, ogień, ciśnienie pod powierzchnia wody i ciecze agresywne.

Stowa kluczowe: rejestrator katastroficzny, badania odporności 
Testing the catastrophic recorder resistance against the impact of catastrophic... Badania odporności rejestratora katastroficznego na oddziaływanie czynników...

\section{TESTING THE CATASTROPHIC RECORDER RESISTANCE AGAINST THE IMPACT OF CATASTROPHIC FACTORS}

\section{Introduction}

The design and incorporation of the systems used in aviation requires meeting specific standards and regulations of the aviation law. The document specifying the requirements for catastrophic recorders of flight parameters is the defence standard NO-16-A200 [1] and European standard EuroCAE ED-112 [2]. The subject of the study was the catastrophic recorder of the S2-3a flight parameters recording system developed at the Air Force Institute of Technology. Both the electronic systems and mechanical elements of the catastrophic recorders, usually referred to as the "black boxes", undergo a series of tests that verify their reliability and resistance against the impact of environmental and strength factors.

The criterion for meeting the requirements of resistance against the impact of catastrophic factors is the "recoverability" of the data recorder in the catastrophic recorder's memory. It is acceptable to include strains as well as the recorder's mechanical and electrical damage that allow recovering the recorded data and reproducing the time waveforms for all parameters.

\section{Test object}

The catastrophic recorder consists of elements that are to protect the semiconductor memory packages against mechanical and climactic exposure possible in case of an aerial accident (catastrophe). The catastrophic recorder's cross-section is presented in fig. 1 [3].

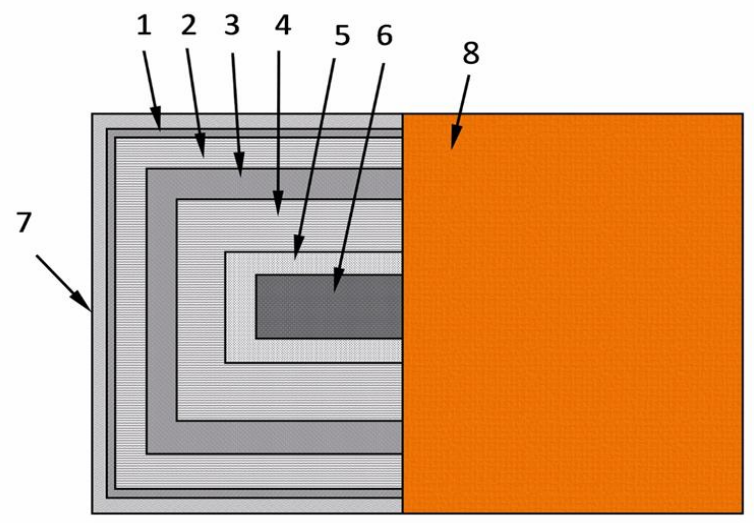

Fig. 1 Catastrophic recorder-cross-section: 1 - steel enclosure,

2 - micro-porous thermal insulation material I-external insert, 3 -titanium enclosure, 4 - micro-porous thermal insulation material II - internal insert,

5 -flexible silicone rubber mass, 6 - electronics packages,

7 -fire-resistance coating, $\quad 8$-external enclosure 
The catastrophic recorder's fire-protection coating was covered with the Flame Stal (FS) swelling solvent fire-protection paint, reinforced with a fibre glass mesh. The view of the catastrophic recorder is presented in fig. 2.

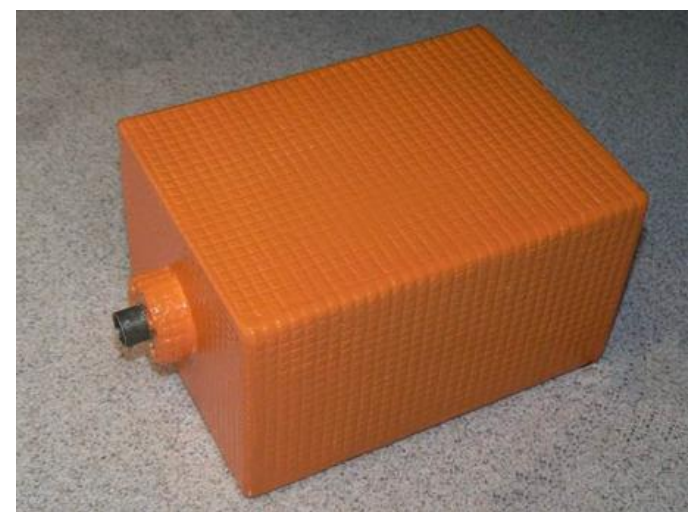

Fig. 2 Catastrophic resistance [4]

\section{Scope of testing}

The testing of the resistance against the impact of aerial catastrophic factors includes a series of tests simulating the exposure that can take place during an aerial catastrophe. Prior to commencing the tests, it is necessary to record the test data in the memory located inside the catastrophic recorder. During testing, it is only acceptable to control the memory contents (it is not acceptable to refresh the data or disassemble or repair the structural elements). The testing of the resistance against the impact of aerial catastrophic factors encompasses the following factors [1, 2]:

a) overstress taking place at impact of 3,400 $\mathrm{g}$ for approx. $6.5 \mathrm{~ms}$;

b) puncture with a cylindrical dowel pin with the diameter of $6.35 \mathrm{~mm}$ and weight of $227 \mathrm{~kg}$, falling from the height of $3 \mathrm{~m}$;

c) static compression with a force of $22 \mathrm{kN}$ for $5 \mathrm{~min}$;

d) fire with a heat flux of $158 \mathrm{~kW} / \mathrm{m}^{2}$, temperature of $1,100{ }^{\circ} \mathrm{C}$ with an exposure time of at least $30 \mathrm{~min}$;

e) pressure under the water surface of $60 \mathrm{MPa}(6,000 \mathrm{~m})$ for at least $24 \mathrm{~h}$;

f) aggressive liquids (oil, fuels, salty water).

During the testing, it was required to maintain the sequence of tests specified in points a) to f).

\section{Testing the catastrophic recorder resistance against the overstress taking place at impact}

Testing the resistance against the overstress taking place at impact is based on subjecting the catastrophic recorder to sinusoidal overstress with the amplitude of $33,354 \mathrm{~m} / \mathrm{s}^{2}(3,400 \mathrm{~g})$ for a half of its duration of $6.5 \mathrm{~ms}$. Instead of sinusoidal overstress, it is acceptable to apply an equivalent trapezoidal overstress with the waveform presented in fig. 3 . 
Testing the catastrophic recorder resistance against the impact of catastrophic... Badania odporności rejestratora katastroficznego na oddziaływanie czynników...

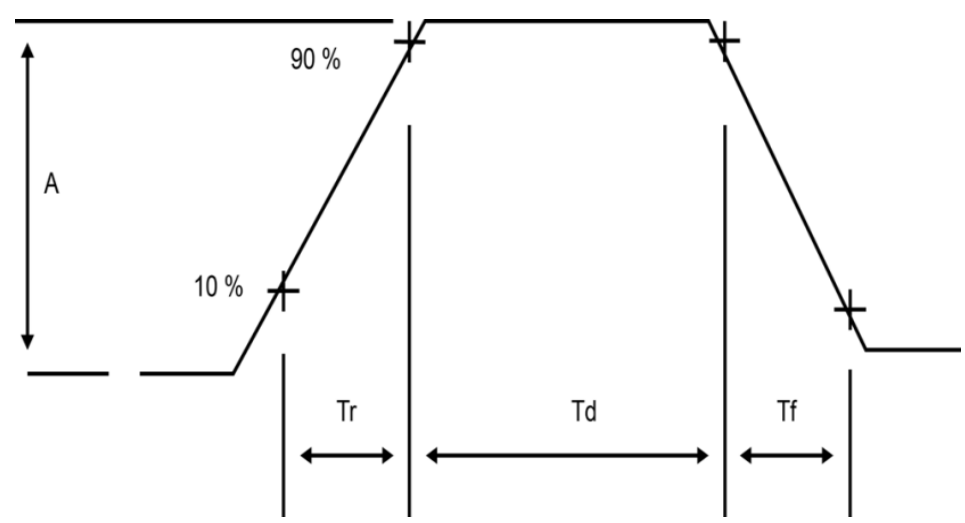

Fig. 3 Waveform of an equivalent trapezoidal overstress affecting the catastrophic recorder:

$A=\min .3,400 \mathrm{~g}\left(33,354 \mathrm{~m} / \mathrm{s}^{2}\right), T_{r}=\max .3 .5 \mathrm{~ms}, T_{d}=\min .3 .0 \mathrm{~ms}, T_{f}>0.0 \mathrm{~ms}$

In the test aimed at demonstrating the fulfilment of the catastrophic recorder's resistance requirements for an overstress of $3,400 \mathrm{~g}$, it is possible to distinguish two basic notions:

- accelerating the object to a velocity that allows reaching the required overstress;

- braking the object according to the required characteristics.

Due to the lack of access to the devices specified in the standard, a method of coercion and measuring the required overstress based on a pneumatic cannon was developed. We chose the DPZ-250 pneumatic cannon in the Air Force Institute, the features of which allow testing of objects with a weight of up to $15 \mathrm{~kg}$.

A sand deposit obstacle was chosen to brake the test object.

In order to obtain the required overstress value, it is necessary to stop the object when it is moving at $520 \mathrm{~km} / \mathrm{h}$ on a path of $0.23 \mathrm{~m}$. The physical interpretation of the test requirements is presented in fig. 4.

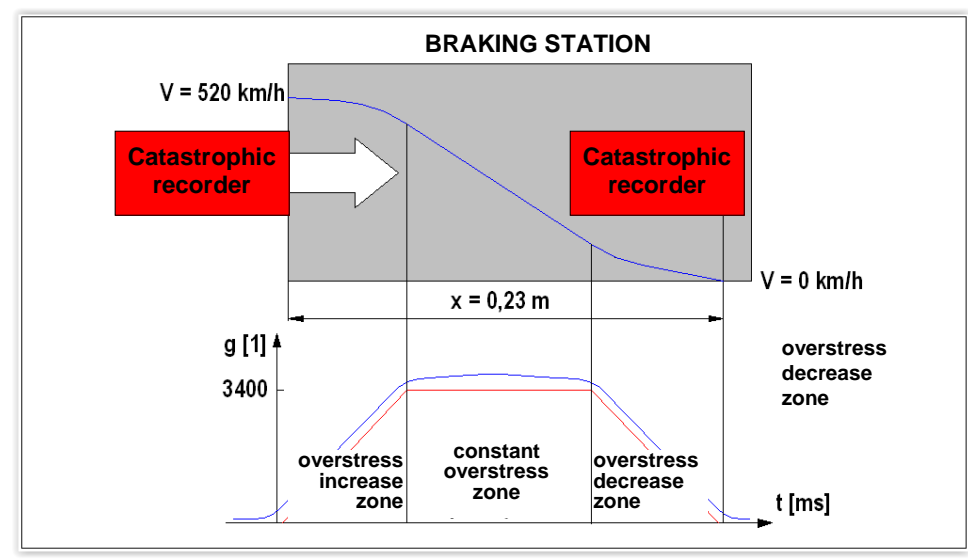

Fig. 4 Physical interpretation of the test's requirements 
In terms of conducting the tests, the most important aspect is the change in the test object's velocity in the adopted braking station environment, i.e. sand. The sand's specific weight has primary impact on the dynamics of changes in the test object's velocity. The comparative description of changes in velocity depending on the sand density is presented in fig. 5. The following sand density was adopted for comparison:

- for the waveform simulated in accordance with the proposal of D. Fiserova [5],

- for the waveform simulated in accordance with the ANSYS AUTODYN program database,

- for the experimental waveform.

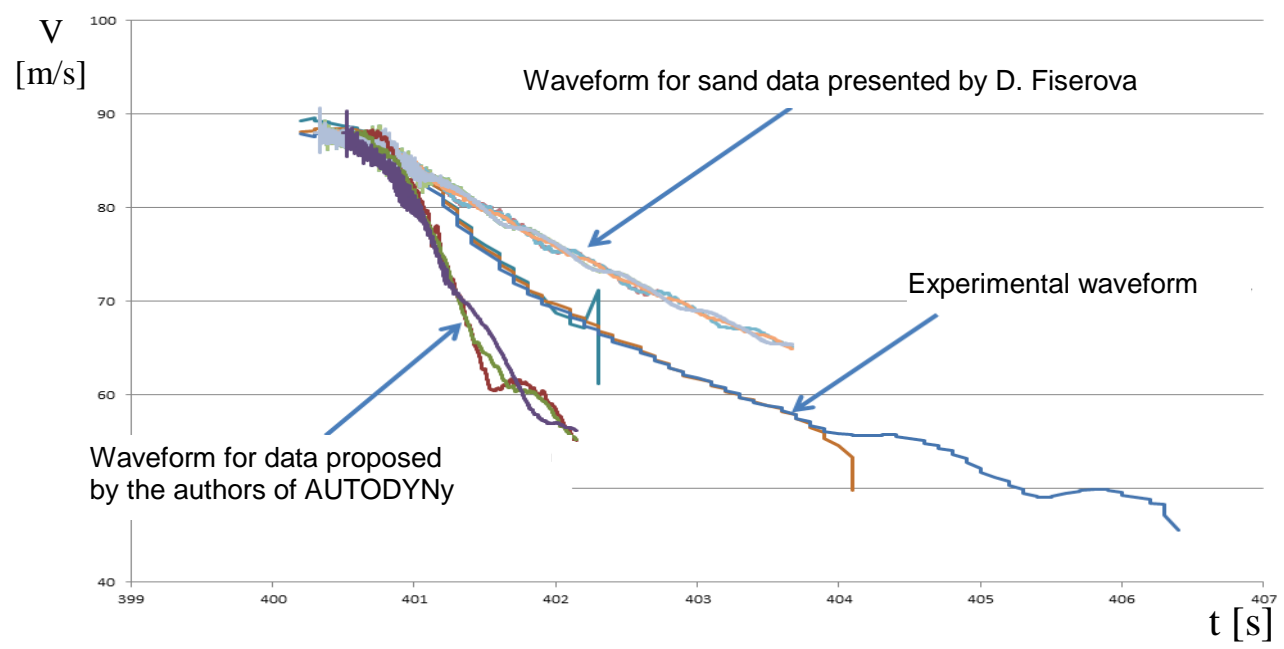

Fig. 5 Description of changes in velocity in the function of time depending on the sand density

The elements constituting the conducted experiment include:

- pneumatic cannon - station propelling the test object;

- test probe - element that allows enclosing the proper test object, i.e. catastrophic recorder's electronics package;

- braking station - element that ensures stopping the test object;

- camera for recording fast-changing processes;

- impact recorder (placed in the test probe) - optional;

- impact measurement sensors (placed in the test probe) - optional;

- floodlights illuminating the shot zone.

The diagram of the measurement station is presented in fig. 6 . 
Testing the catastrophic recorder resistance against the impact of catastrophic... Badania odporności rejestratora katastroficznego na oddziaływanie czynników...

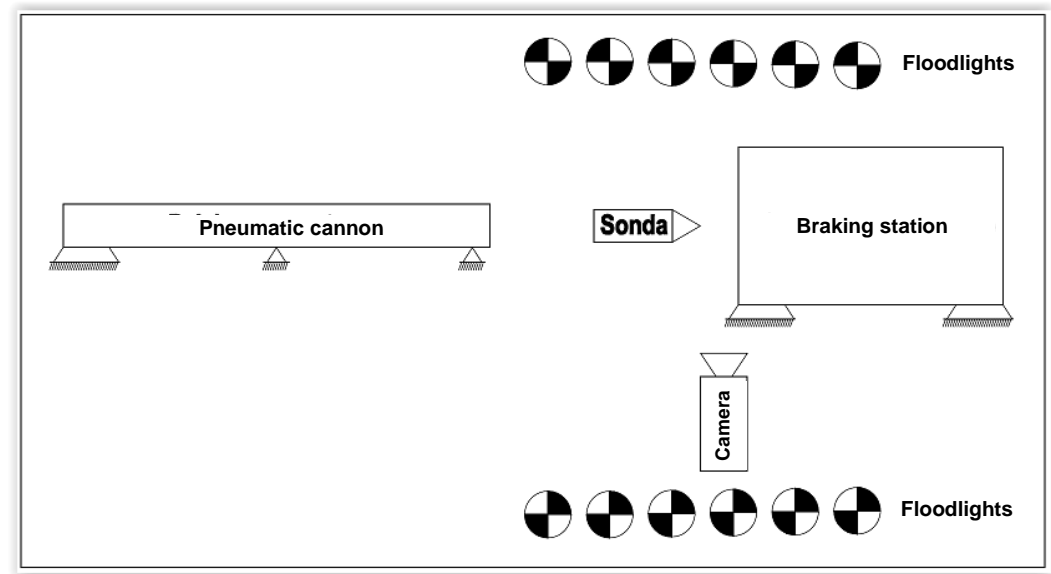

Fig. 6 Diagram of the measurement station

The purpose of using the cannon is to give the test object velocity. The DPZ-250 pneumatic cannon was used to give the test object the required velocity.

Basic technical data of the DPZ-250 cannon:

- barrel diameter $-250 \mathrm{~mm}$;

- barrel length $-8 \mathrm{~m}$;

- max. weight of the test object $-15 \mathrm{~kg}$;

- min. weight of the test object $-0.9 \mathrm{~kg}$;

- test object velocity for max. weight $-180 \mathrm{~m} / \mathrm{s}$;

- test object velocity for min. weight $-310 \mathrm{~m} / \mathrm{s}$;

- max. pressure - 10 bar.

The basic information when using the cannon is the weight of the fired object and the object's required velocity after it leaves the barrel. In the case of using the cannon, it is most important to know the dependency $V=f(p)$, i.e. the cannon velocity and the pressure of air used for the shot. The view of the DPZ-250 cannon is presented in fig. 7 .

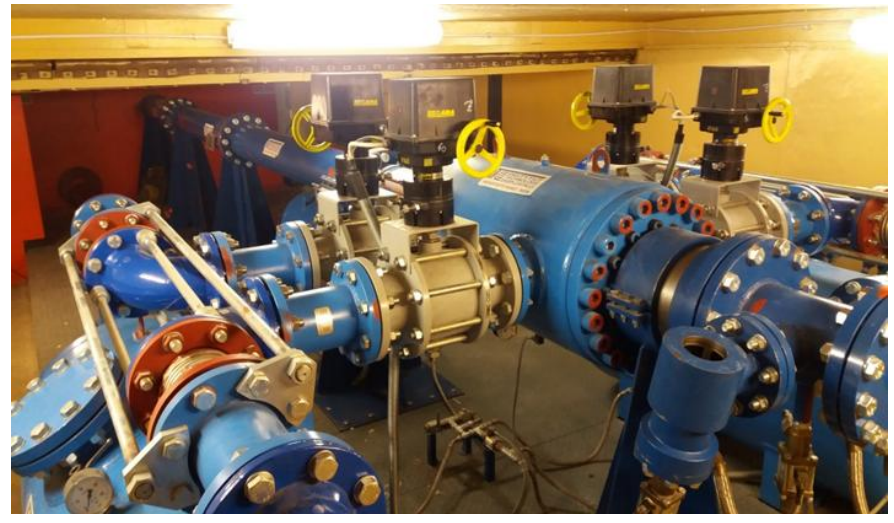

Fig. 7 DPZ 250 pneumatic cannon (Institute of Aviation) 
Zbigniew Jakielaszek, Grzegorz Kowaleczko, Andrzej J. Panas, Mirostaw Nowakowski

The feature $V=f(p)$ for the selected weights of the test objects is presented in fig. 8 .

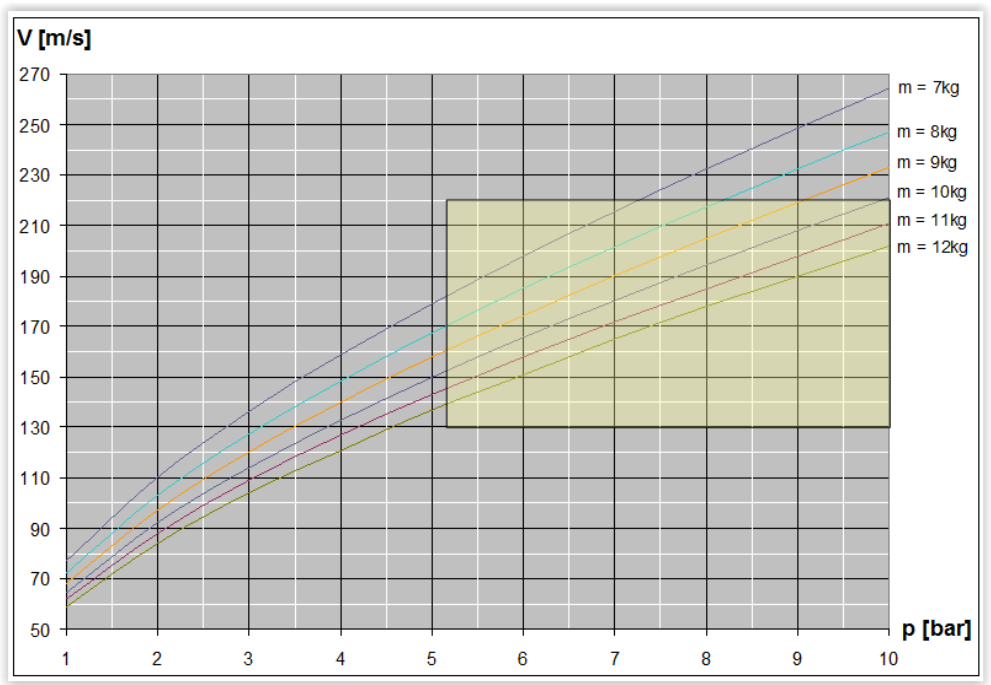

Fig. 8 Feature $V=f(p)$ of the DPZ-250 pneumatic cannon

The test object used for determining the catastrophic recorder's impact test parameters was a test probe. Probes of various shapes were used in particular test stages. At the beginning, these included probes made from steel, equivalent in weight and cubic capacity to the catastrophic recorder, and in weight, allowing the assembly of the impact recorder. The view of the first measurement probes is presented in fig. 9 .

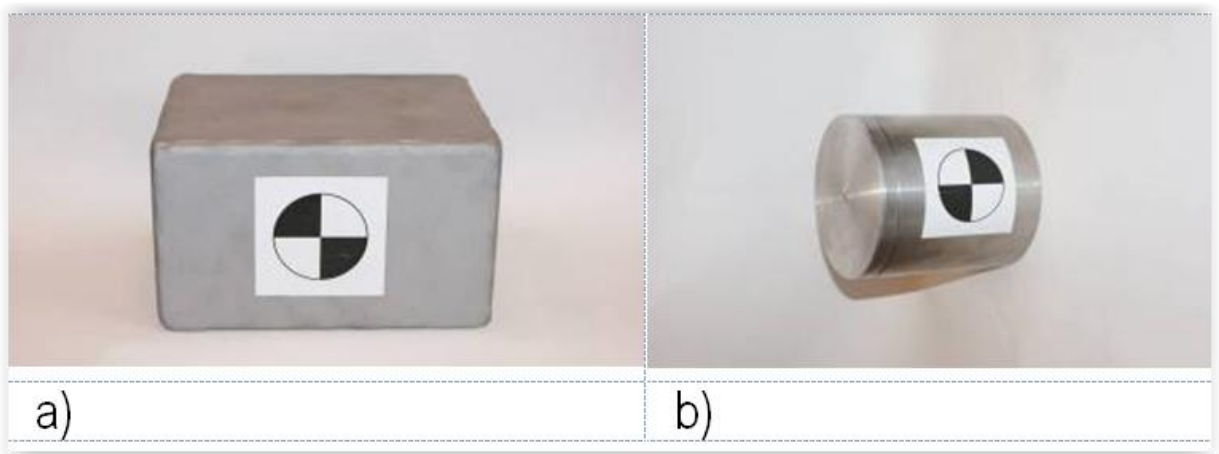

Fig. 9 View of measurement probes: a) weight and cubic capacity equivalent; b) weight equivalent adapted to the recorder's enclosure

In the next stage, we used probes equipped in the front with conical penetrators with a flare angle of $90^{\circ}$ and $60^{\circ}$, with various weights and lengths. The view of the probes along with the polyacetal body is presented in fig. 10 . 
Testing the catastrophic recorder resistance against the impact of catastrophic... Badania odporności rejestratora katastroficznego na oddziaływanie czynników...

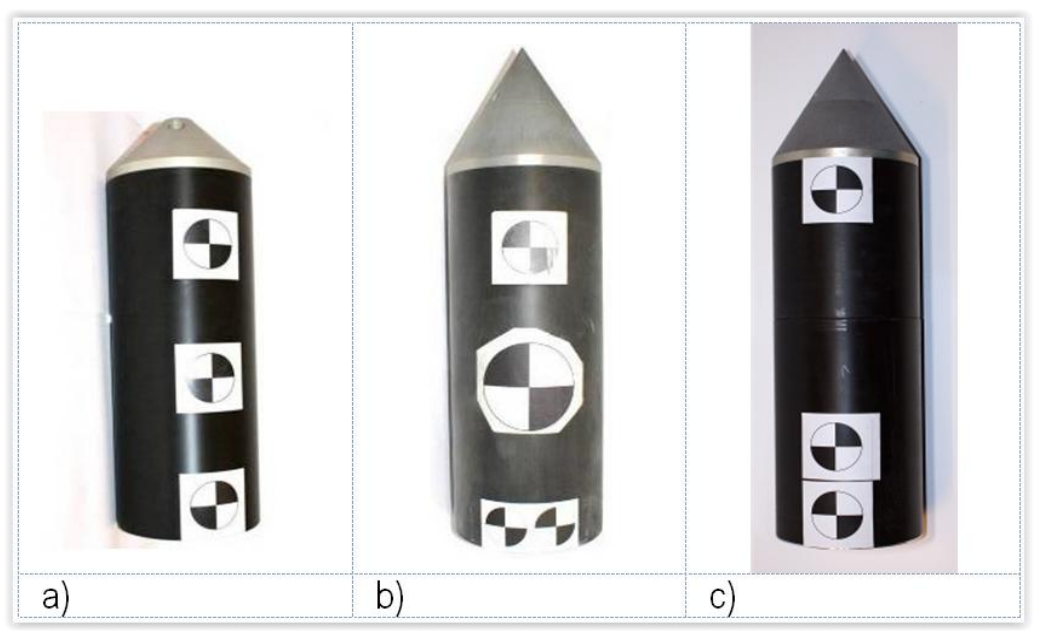

Fig. 10 View of the test probes with a polyacetal body: a) probe with a penetrator with a flare angle of $90^{\circ}, b$ ) probe with a penetrator with a flare angle of $60^{\circ}$, c) probe with a penetrator with a flare angle of $60^{\circ}$, and body with hollow space for the electronics package

The last stage of testing included the use of probes with the following lengths: 641 $\mathrm{mm}$ and $846 \mathrm{~mm}$ with a penetrator with a flare angle of $60^{\circ}$, with the "long" and "medium" designation, made from Pa-9 duralumin. The diagram of the probe's structure and view of the "medium" and "long" probe is presented in fig. 11.

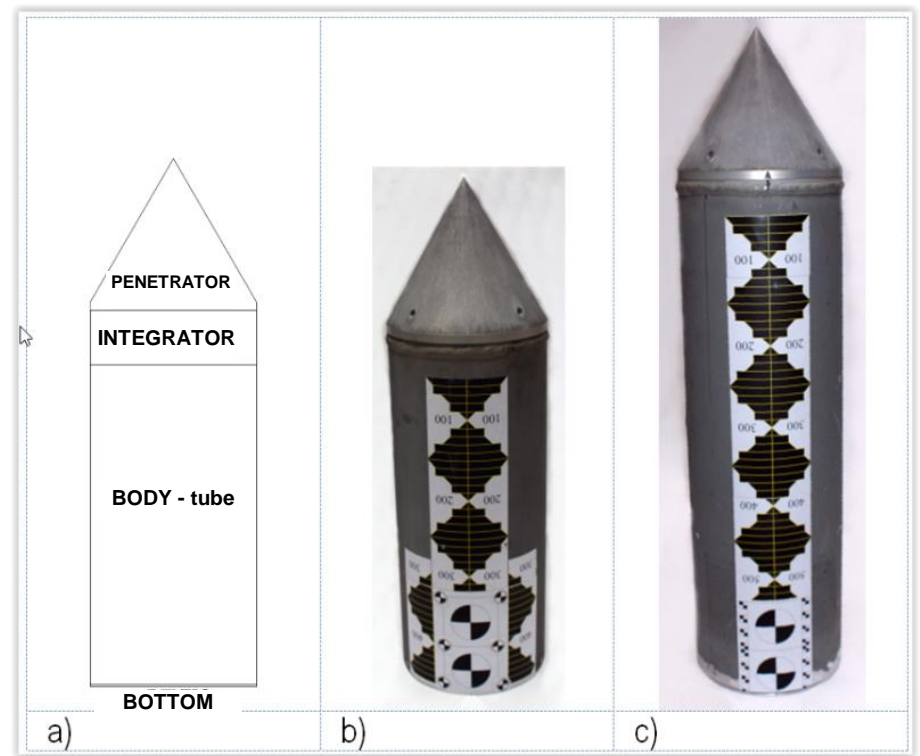

Fig. 11 View of the measurement probes made from duralumin:

a) description of the probes components, b) "medium" probe, c) "long" probe 
Due to the difficulties with using an independent recording system, it was necessary to record the entire test using the PHANTOM V711 camera. The "medium" and "long" measurement probe was designed due to the above. The "long" probe is intended for ensuring a sufficiently long recording, while the "medium" probe, by maintaining identical weight, ensures the enclosure of the catastrophic recorder's electronics package. The electronics package was placed in a thermal insulation material cover in a titanium-imitating enclosure of the catastrophic recorder. The course of the test was recorded in the electronics package's memory. Due to the fact that the probes had identical weight, they were launched with the same cannon loading pressures.

Test data using the "medium" probe:

- probe length: $641 \mathrm{~mm}$;

- probe weight: $8,905 \mathrm{~kg}$;

- total projectile weight: $11,455 \mathrm{~kg}$;

- pneumatic cannon working pressure: 9.5 bar.

Data concerning testing using the "long" probe:

- probe length: $846 \mathrm{~mm}$;

- probe weight: $8.9 \mathrm{~kg}$;

- total projectile weight: $11.5 \mathrm{~kg}$;

- pneumatic cannon working pressure: 9.5 bar.

The course of the testing was recorded using the PHANTOM V711 type camera intended for fast-changing phenomena, which allowed recording the image with the rate of 24,000 frames per second with the resolution of $1280 \times 240$. The recording examples are presented in fig. 12.

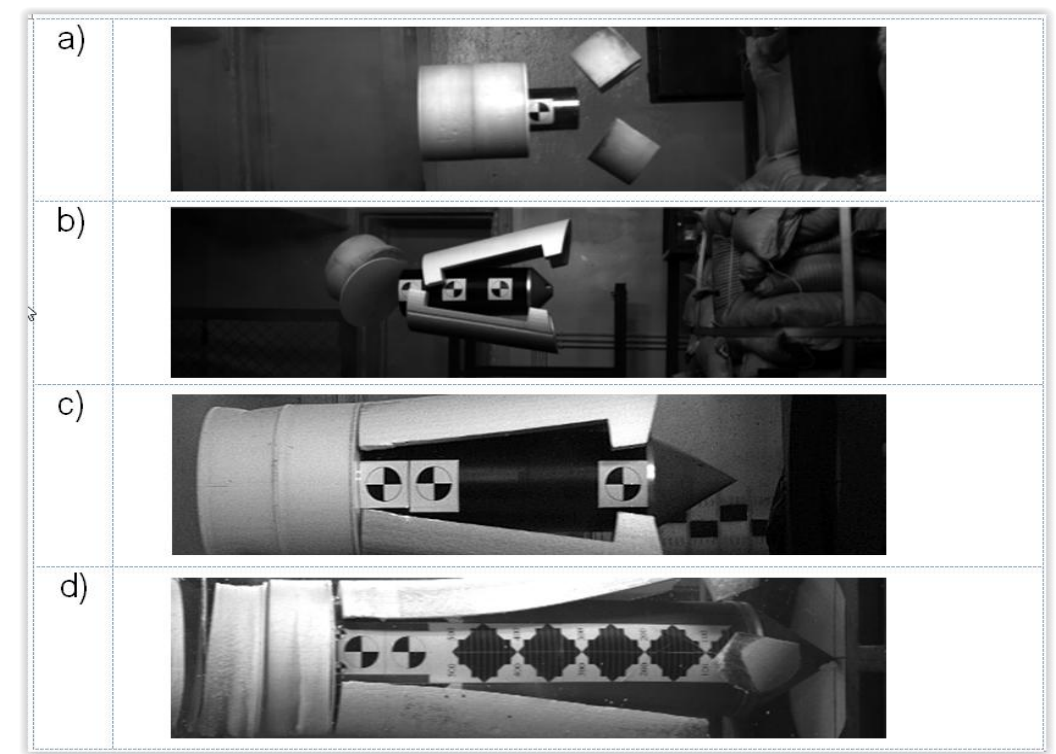

Fig. 12 View of sample probes in the last stage of flight: a) weight equivalent, b) polyacetal probe with a penetrator with a flare angle of $90^{\circ}$,

c) drilled polyacetal probe with a penetrator with a flare angle of $60^{\circ}$,

d) "long" duralumin probe with a penetrator with a flare angle of $60^{\circ}$ 
Testing the catastrophic recorder resistance against the impact of catastrophic... Badania odporności rejestratora katastroficznego na oddziaływanie czynników...

The purpose of the testing was to obtain information about the overstress and duration of the measurement probe and obstacle impact phenomenon. The sand deposit obstacle was used to stop the probe in comparable conditions. The first, exploratory testing included the use of a prism arranged from bags filled with sand. The view of the original braking station is presented in fig. 13 .

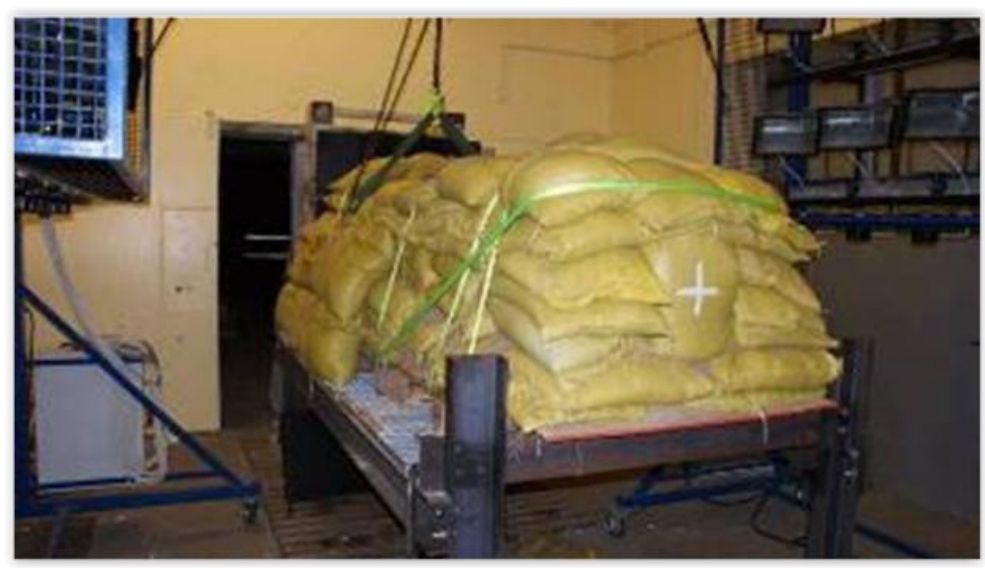

Fig. 13 View of the original braking station

In the final stage, for high velocity impact testing, we developed a braking station in the form of a sand container consisting of five sufficiently reinforced segments. The view of the braking stations is presented in fig. 14 .

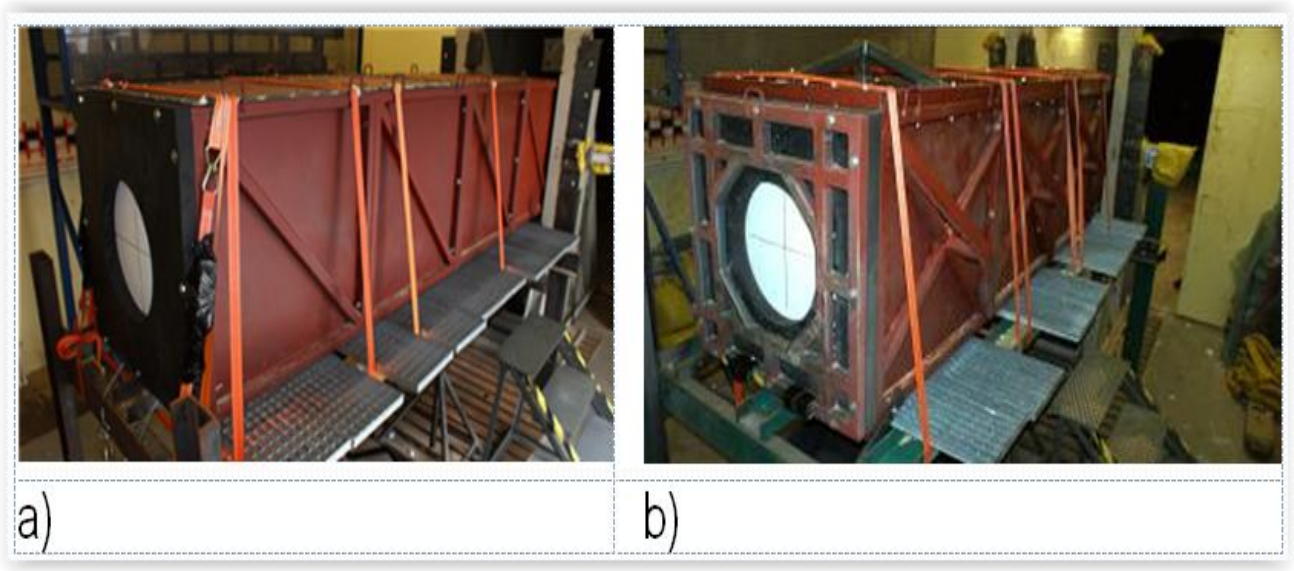

Fig. 14 View of the braking station in the form of a sand container: a) starting sand container solution, $b$ ) final, reinforced braking station version 
Zbigniew Jakielaszek, Grzegorz Kowaleczko, Andrzej J. Panas, Mirosław Nowakowski

The waveforms of velocity changes after contact of the probes with the braking station for the "medium" and "long" probe is presented in fig. 15.

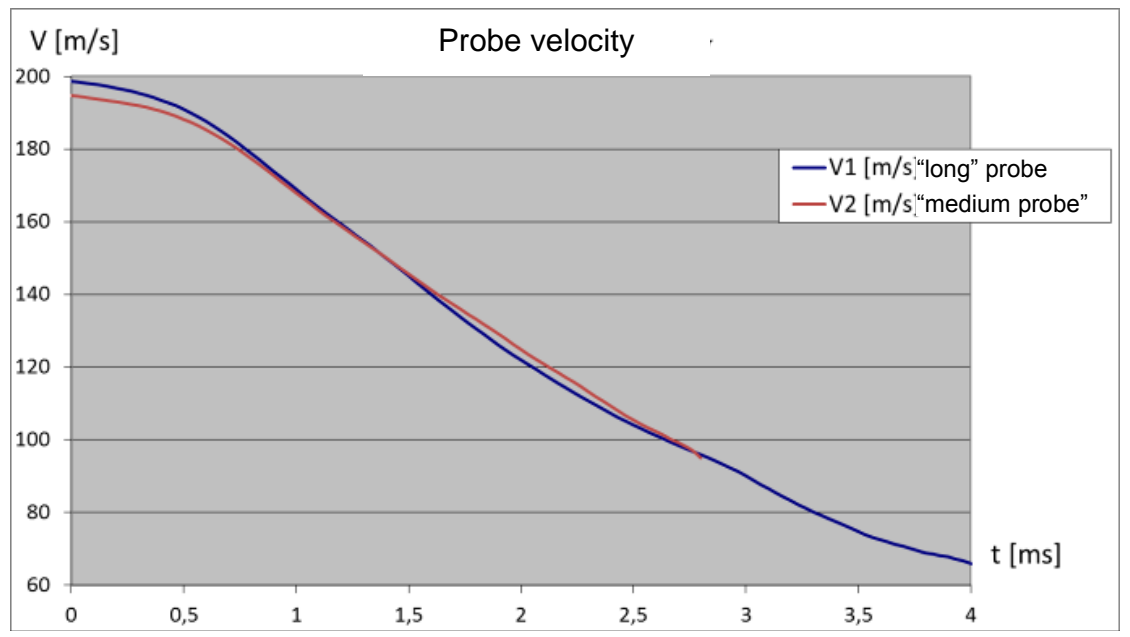

Fig. 15 Waveforms of probe brake rate changes

The waveforms of changes in acceleration and the normative acceleration estimated on this basis are presented in fig. 16.

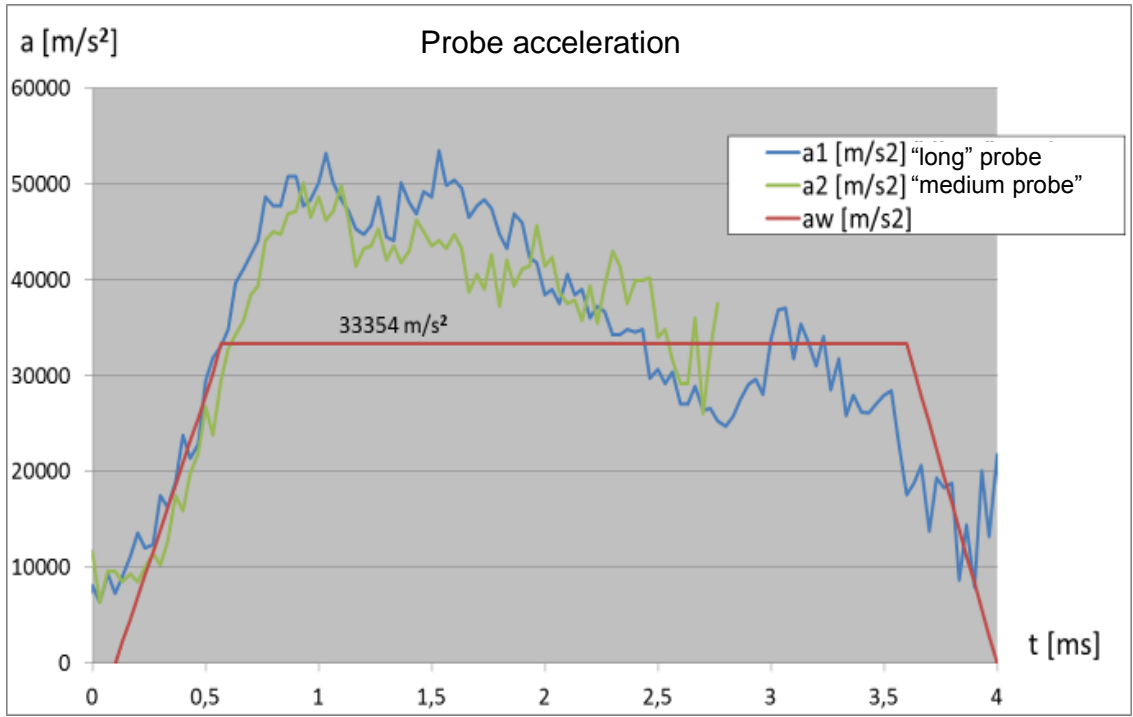

Fig. 16 Waveforms of changes in probe acceleration in relation to the required impulse 
Testing the catastrophic recorder resistance against the impact of catastrophic... Badania odporności rejestratora katastroficznego na oddziaływanie czynników...

The obtained acceleration is higher than the required value by over $2.5 \mathrm{~ms}$ and is slightly lower in the end fragments of the recording, in the range from $2.5 \mathrm{~ms}$ to 3.0 $\mathrm{ms}$ and above $3.3 \mathrm{~ms}$. The result was obtained at limit capabilities and it applies for the used weight of the measuring probes.

During the test of specifying the catastrophic recorder's impact profile we confirmed the effectiveness of the adopted methodology and procedures aimed at determining the test object's behaviour when braking in sand.

The catastrophic recorder's electronics packages used twice during the tests have maintained the recorded data, which were subsequently successfully reproduced.

We were not able to recreate the conditions specified in the standard during the experiments, but the higher starting velocity and accelerations during braking demonstrate that the quantities of dispersed energy are higher than the standard's requirements. It is thus possible to state that the test exposures were higher than required. The analysis of the data from the conducted experiments indicates however that by using a pneumatic cannon, including slight structural changes in the test probe, it is possible to obtain the required braking profile of the tested object.

\section{Testing the catastrophic recorder resistance against puncture}

The test is based on puncturing the catastrophic recorder with a steel cylindrical dowel pin with the diameter of $(6.35 \pm 0.1) \mathrm{mm}$, length of protruding end of $(40 \pm 1) \mathrm{mm}$, hardness from $39 \mathrm{HRC}$ to $45 \mathrm{HRC}$ and deadweight with a weight of $227 \mathrm{~kg}$, falling from the height of $3 \mathrm{~m}$.

The station for testing the recorder's resistance against dowel pin puncture is presented in fig. 17.

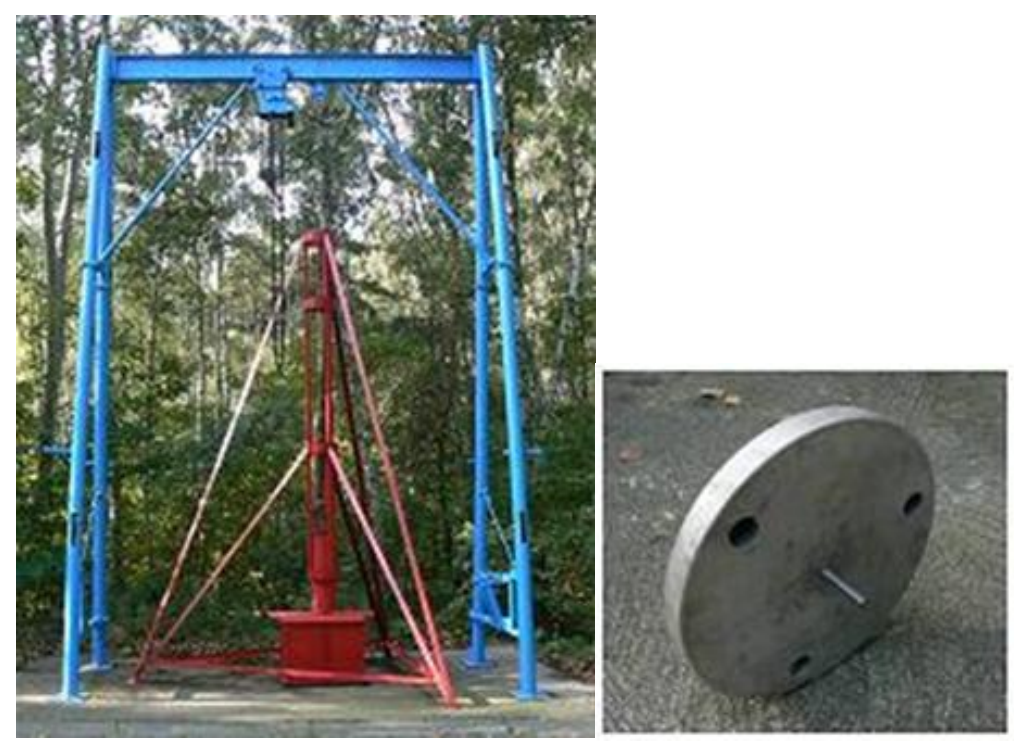

Fig. 17 Station for testing the recorder's resistance against dowel pin puncture 
According to the defence standard, the testing of the catastrophic recorder's resistance against impact-induced puncture has not exceeded $20 \%$ of the starting recorder volume.

\section{Testing the catastrophic recorder resistance against static compression}

The test is based on subjecting the catastrophic recorder to uniaxial static compression with a linearly growing strength of up to $22 \mathrm{kN}$, which affected the cassette after reaching the maximum value for $5 \mathrm{~min}$. The test is conducted using a hydraulic press, in which the contact force measurement is conducted with a manometer that measures the liquid's pressure (fig. 18). The catastrophic recorder is supported in the contact axis with round, flexible pads with the diameter of $5 \mathrm{~cm}$ and thickness of $1.25 \mathrm{~cm}$.

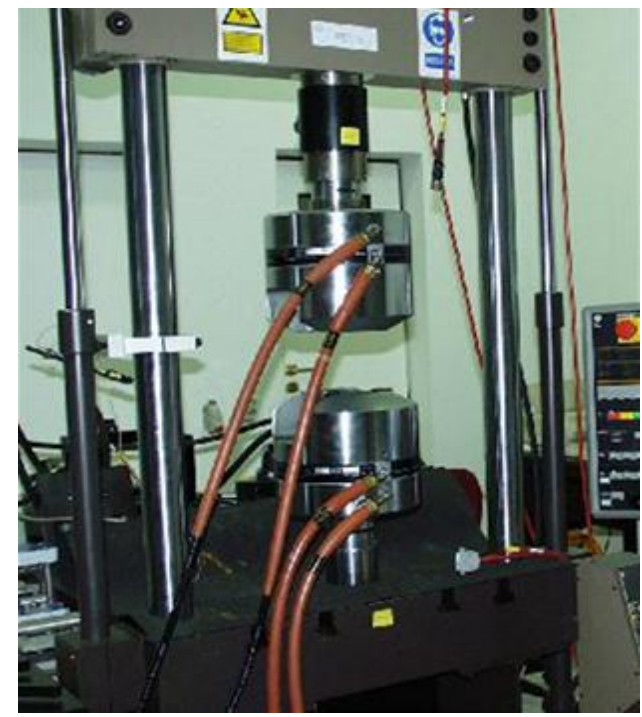

Fig. 18 Station for testing the catastrophic recorder's resistance against static compression

The testing of the catastrophic recorder's resistance against static compression is deemed positive if after removing the load, the dents caused by the impact of force give away and the recorded test information is fully maintained.

\section{Testing the catastrophic recorder resistance against exposure to fire}

In accordance with the NO-16-A200 standard, the catastrophic recorder is required in terms of fire resistance to recover all data recorded in the memory after conducting the test in the following conditions:

- fire with a minimum heat flux of $158 \mathrm{~kW} / \mathrm{m}^{2}$;

- minimum flame temperature of $1,100{ }^{\circ} \mathrm{C}$, measured in the distance of $25 \mathrm{~mm}$ from the recorder's surface; 
Testing the catastrophic recorder resistance against the impact of catastrophic... Badania odporności rejestratora katastroficznego na oddziaływanie czynników...

- time of exposure to fire of the entire external recorder surface for at least 30 minutes, continuously;

- recorder cooling after the test in a natural manner to the ambient temperature. The catastrophic recorder on the test station is presented in fig. 19.

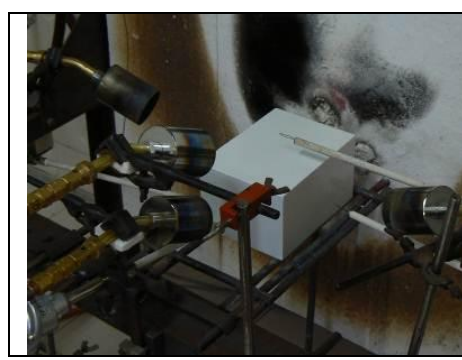

a)

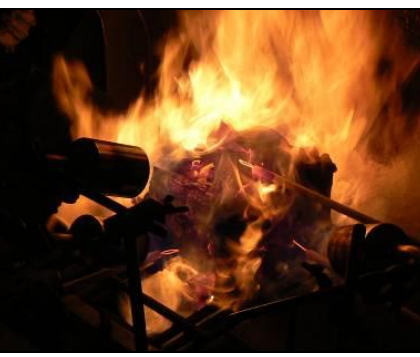

b)

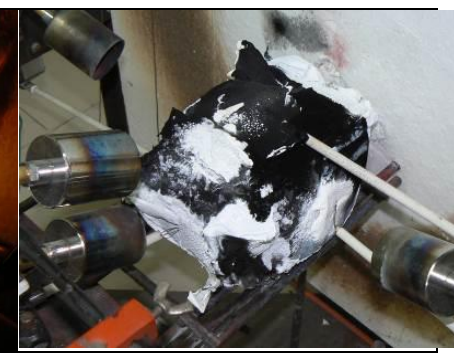

c)

Fig. 19 View of the catastrophic recorder on the test station: a) before the test, $b$ ) during the test, c) after the test [6]

The sample results of testing the catastrophic recorder coated with a fire protection coating with the thickness of approx. $2 \mathrm{~mm}$, made from the Flame Stal solvent paint reinforced with a fibre glass mesh, with a thermal insulation insert and from a micro-porous material with the thickness of $15 \mathrm{~mm}$, in which a reinforced cassette was placed, and an electronic module in it with the recorded test information, filled with flexible silicone rubber mass is presented in fig. 20.

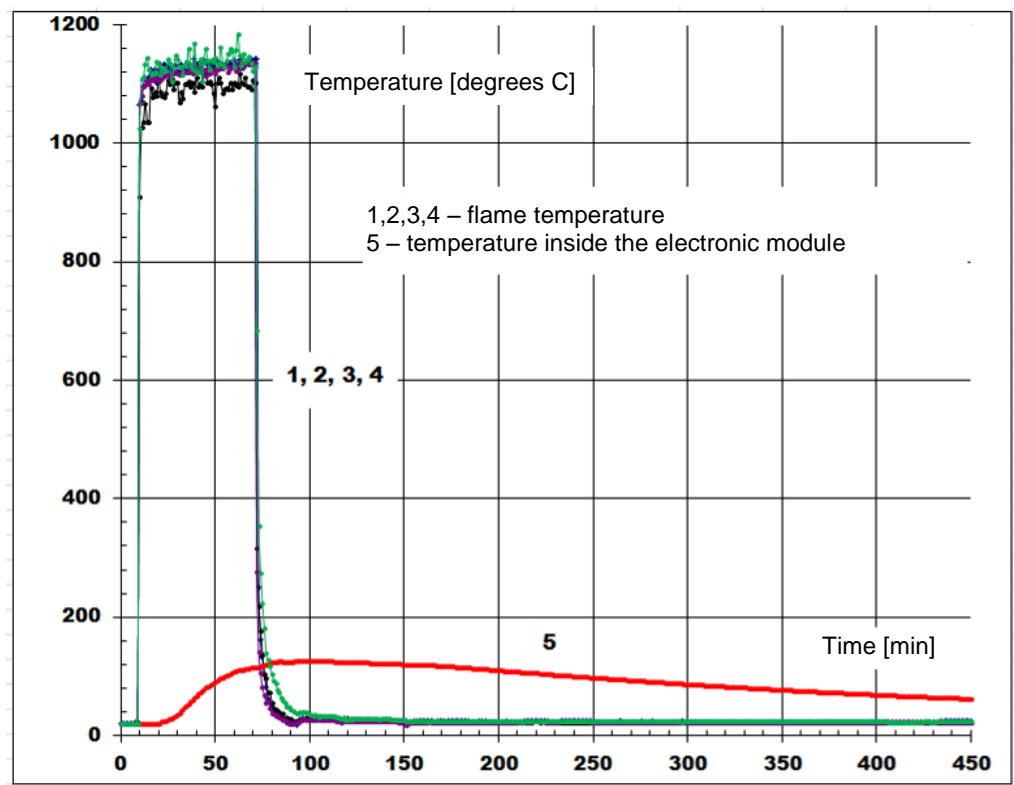

Fig. 20 Dependency of the temperature inside the catastrophic recorder and flame temperature on time [7] 
The conducted testing of the catastrophic recorder in terms of resistance against exposure to fire demonstrates that the recorded test information was maintained in full. The recorded information lasted a 1-hour test in fire with the temp. of $1,100^{\circ} \mathrm{C}$. The temperature inside the catastrophic recorder for the electronic module amounted to $\leq 130^{\circ} \mathrm{C}$.

\section{Testing the catastrophic recorder resistance against pressure below the water} surface

The testing is based on subjecting the flight recorder's pressurisation process in conditions simulating submersion in the environment of seawater at the depth of $6 \mathrm{~km}$, which corresponds to the pressure of $60 \mathrm{Mpa}$, acting on the catastrophic recorder for 24 hours. A key factor in the designing of the test chamber for recorder pressurisation was the determination of the compressibility of the medium in which the catastrophic recorder was submerged. The compressibility of seawater, i.e. its susceptibility to volume strains in case of pressure changes, was based on testing in a special experimental device that allows determining the compressibility of water and of $\mathrm{NaCl}$ aquatic salt solutions [8].

Based on the conducted laboratory tests, we estimated the changes in the volume of $\mathrm{NaCl}$ aquatic solutions in relation to their starting volume $(\Delta V / V)$, expressed in percentage, and determined the compressibility factor. The nature of the volume changes and compressibility factors under pressure for the tested solutions is presented in fig. 21 and fig. 22.

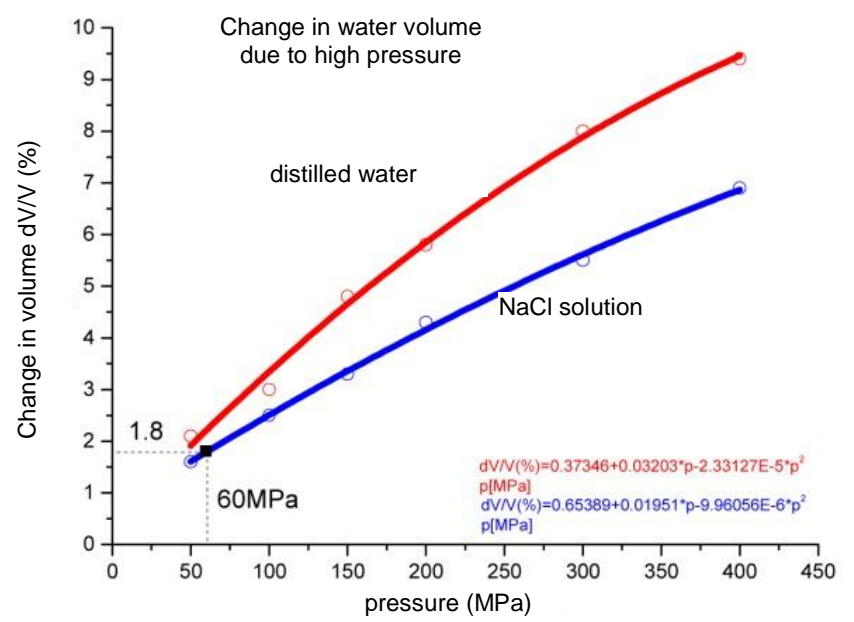

Fig. 21 Change in the volume of water solutions due to high pressures 
Testing the catastrophic recorder resistance against the impact of catastrophic... Badania odporności rejestratora katastroficznego na oddziaływanie czynników...

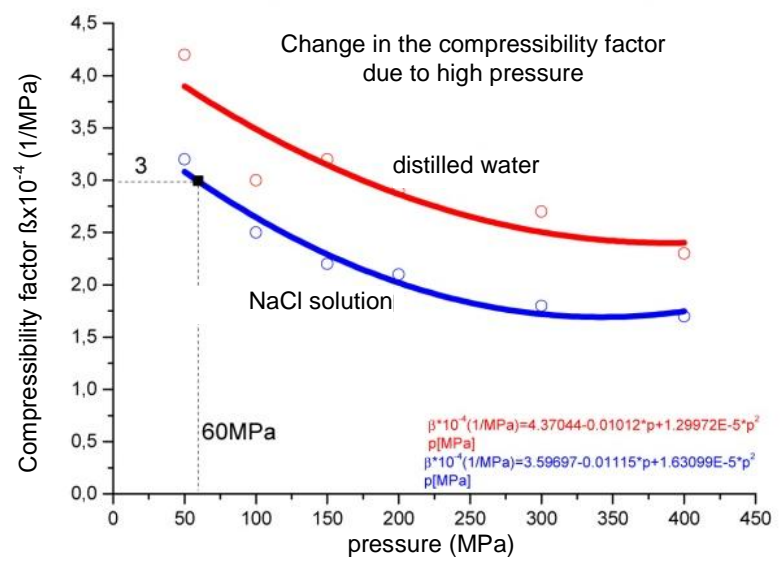

Fig. 22 Nature of changes in the compressibility factor of aquatic solutions under high pressures

The station consists of the feeding part and the high-pressure working part. The feeding part is a press located at the Polish Academy of Science's, at the Institute of High Pressure Physics, consisting of a working chamber and a pressure multiplier (fig. 23). The high-pressure working part for pressurisation consists of a single-shell chamber for maximum working pressure of $60 \mathrm{MPa}$ (fig. 24), made from a polyurethane diaphragm, and a polyurethane tank with the pressurisation medium and a steel chamber. The station is equipped with systems enabling control, recording and acquisition of data during the pressurisation process. The feeding press [8] allows generating hydrostatic pressure of up to 1,800 $\mathrm{MPa}$ in the press' working chamber (fig. 23). The pressurisation chamber allows conducting long-term pressure testing in the range of 0 to $60 \mathrm{MPa}$. After reaching the required pressurisation level, the pressurisation chamber is "shut off" from the feeding press by using a manual valve.

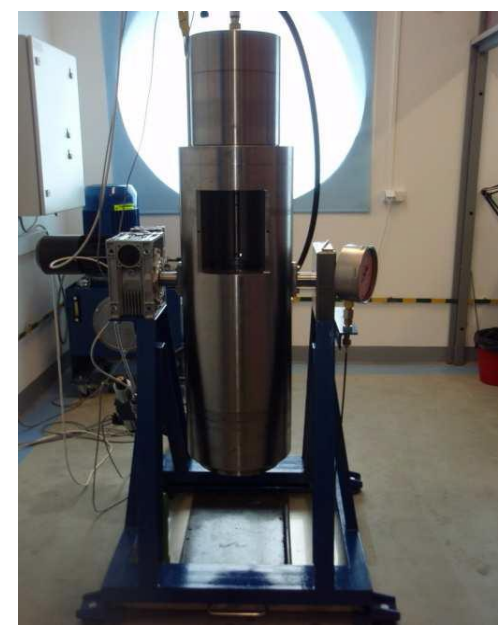

Fig. 23 Press with a pressure multiplier [8] 
Zbigniew Jakielaszek, Grzegorz Kowaleczko, Andrzej J. Panas, Mirostaw Nowakowski

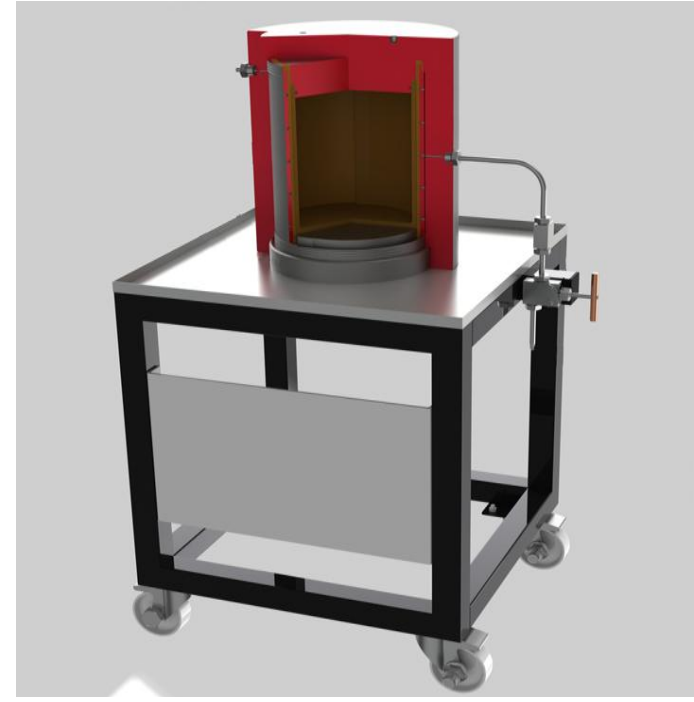

Fig. 24 High-pressure chamber for hydrostatic pressurisation up to $60 \mathrm{MPa}$ [8]

The design of the chamber made from the 45HNMFA steel has undergone a mathematical analysis using the finite elements method and the Ansys Static Structural program. The analysis was conducted for the maximum acceptable load of $p_{H E}=60 \mathrm{MPa}$ with consideration of the safety factor of $n=2$ [8]. Figure 25 presents the analysis of the distribution of nodal stresses in the chamber.

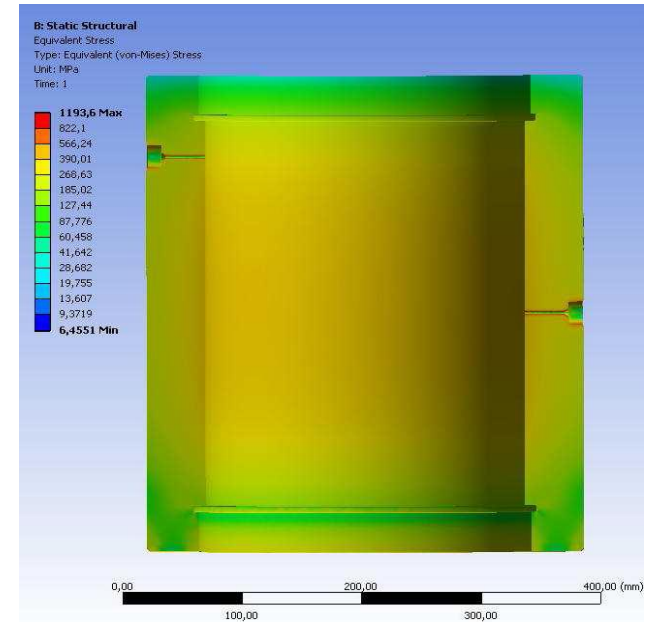

Fig. 25 Distribution of reduced nodal stresses in the pressure chamber at the maximum load of $p_{H E}=60 \mathrm{MPa}$ [8]

The station has undergone operation testing to check the system's tightness, longterm pressure stability and operation of the pressure recording and acquisition system. 
Testing the catastrophic recorder resistance against the impact of catastrophic... Badania odporności rejestratora katastroficznego na oddziaływanie czynników...

The test was conducted on a model object with the volume equal to the volume of the catastrophic recorder. The operating medium's pressure was increased to the maximum pressure of $60 \mathrm{MPa}$. The results of the pressure measurements in the function of time are presented in fig. 26. The rising characteristics illustrate the pressure increase, while their flattening represents the time in which the press' working chamber is shut off using the manual valve and the pressure medium in it is refilled. No system leaks were observed during the increase in pressure.

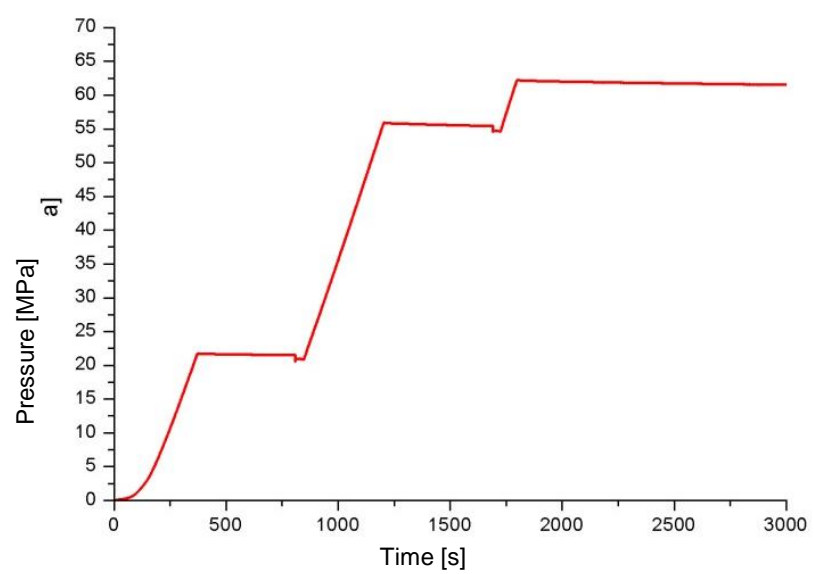

Fig. 26 Pressure chart in the function of time during generation of pressure in the working chamber [8]

Due to the pressure drops related to the cooling of the medium when halting the compression process, it was necessary to generate a respectively higher starting pressure (fig. 27). As result of the tests, it turned out that after a short time of rapid decline, pressure decreased only slightly in the next 20 hours. During the test, the pressure in the pressure chamber was maintained at the min. level of $60 \mathrm{MPa}$ for 24 hours.
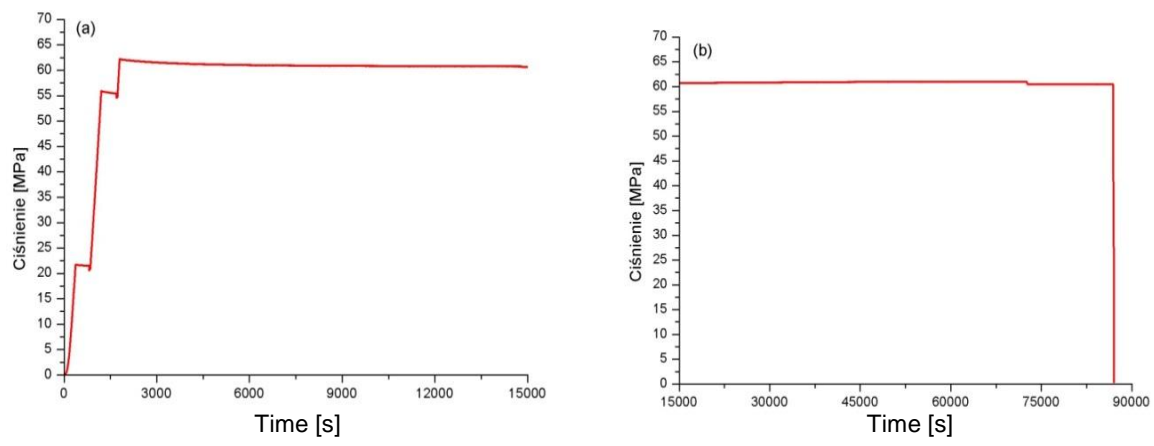

Fig. 27 Pressure chart in the function of time for a full pressurisation cycle [8] 
Zbigniew Jakielaszek, Grzegorz Kowaleczko, Andrzej J. Panas, Mirostaw Nowakowski

The entire testing process was determined by applying the recommendations included in the EuroCAE ED-112 standard. The testing was conducted in the Polish Academy of Sciences' Institute of High Pressure and the Air Force Institute of Technology. Figure 28 presents the catastrophic recorder placed in a pressurisation chamber.

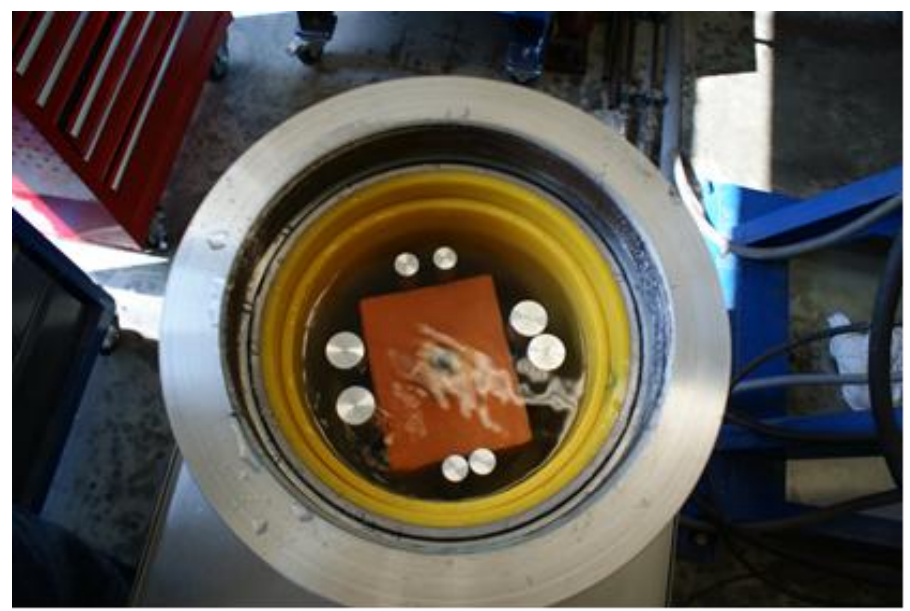

Fig. 28 Open testing station with an installed catastrophic recorder [8]

Test data in a format intended for the Mi-17 helicopter was recorded in the catastrophic recorder's memory. Five over-a-dozen minute recordings of 8 parameters were conducted, including two analogue recordings, simulated using a sinusoidal waveform with the amplitude of up to $5 \mathrm{~V} \mathrm{DC}$ and frequencies of various recordings set to $0.01,0.02$ and $0.03 \mathrm{~Hz}$. Table 1 presents the data read from the cassette prior to commencing the test. It was assumed that a positive test result is the indistinguishability between the data read from the catastrophic recorder's memory prior to and after the test. The data was read using the WTS-5 tester with an installed Objective Recording Analysis (OAZ) decrypting system [9].

Table 1. Values of diagnostic parameters in particular recordings prior to testing [9]

\begin{tabular}{|c|c|c|c|c|c|c|c|c|c|}
\hline $\begin{array}{c}\text { Recording } \\
\text { name }\end{array}$ & $\begin{array}{c}\text { Recording } \\
\text { date }\end{array}$ & $\begin{array}{c}\text { Start of } \\
\text { recording }\end{array}$ & $\begin{array}{c}\text { Recording } \\
\text { duration }\end{array}$ & Diag & $\mathrm{T}$ & $\begin{array}{c}\text { Model } \\
\text { channel }\end{array}$ & NRID & Vpr & Hbar \\
\hline & $\begin{array}{c}\text { D-M- } \\
\text { Y }\end{array}$ & $\mathrm{h}: \mathrm{m}: \mathrm{s}$ & $\mathrm{h}: \mathrm{m}: \mathrm{s}$ & {$[\mathrm{dz}]$} & {$[\mathrm{sec}]$} & {$[\mathrm{dz}]$} & {$[\mathrm{dz}]$} & {$[\mathrm{dz}]$} & {$[\mathrm{dz}]$} \\
\hline 1. & $22-04-14$ & $12: 09: 37$ & $00: 19: 11$ & 0 & $0 \div 1151$ & $2048 \div 2049$ & 696947 & $2049 \div 2050$ & $2557 \div 3581$ \\
\hline 2. & $22-04-14$ & $12: 29: 45$ & $00: 14: 57$ & 0 & $0 \div 897$ & $2048 \div 2049$ & 696947 & $2558 \div 3580$ & $2049 \div 2050$ \\
\hline 3. & $22-04-14$ & $12: 45: 34$ & $00: 14: 58$ & 0 & $0 \div 898$ & $2048 \div 2049$ & 696947 & $2049 \div 2050$ & $2558 \div 3581$ \\
\hline 4. & $22-04-14$ & $13: 01: 08$ & $00: 15: 02$ & 0 & $0 \div 902$ & $2048 \div 2049$ & 696947 & $2557 \div 3581$ & $2049 \div 2050$ \\
\hline 5. & $22-04-14$ & $13: 16: 54$ & $00: 14: 23$ & 0 & $0 \div 863$ & $2048 \div 2049$ & 696947 & $2049 \div 2050$ & $2557 \div 3581$ \\
\hline
\end{tabular}


Testing the catastrophic recorder resistance against the impact of catastrophic... Badania odporności rejestratora katastroficznego na oddziaływanie czynników...

Furthermore, using the prepared laboratory facilities, we conducted a strength test of the catastrophic recorder's electronic system in terms of pressure of the seawater column with the height of $6,000 \mathrm{~m}$ in the time of $24 \mathrm{~h}$.

The hydrostatic pressurisation test was only conducted on electronics in a flexible silicone rubber mass. The description of pressure acting on the electronics package in the function of time is presented in fig. 29. The status of electronic elements is presented in fig. 30 .

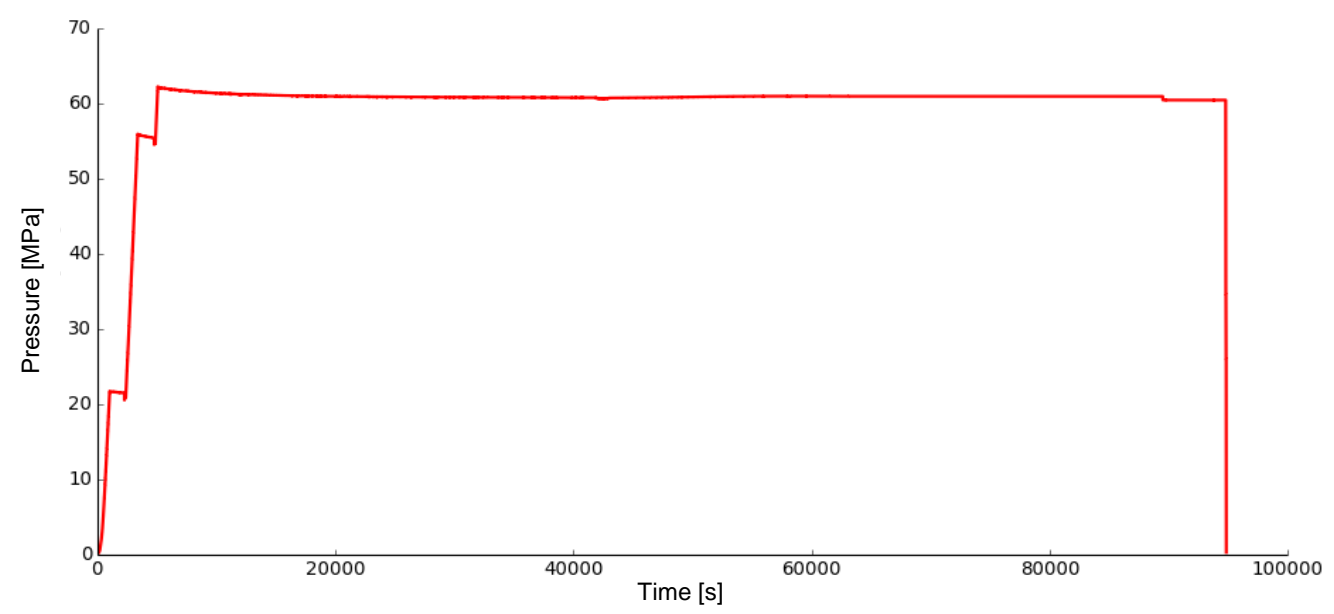

Fig. 29 Pressure feature in the function of time for the pressurisation of the catastrophic recorder's electronic systems

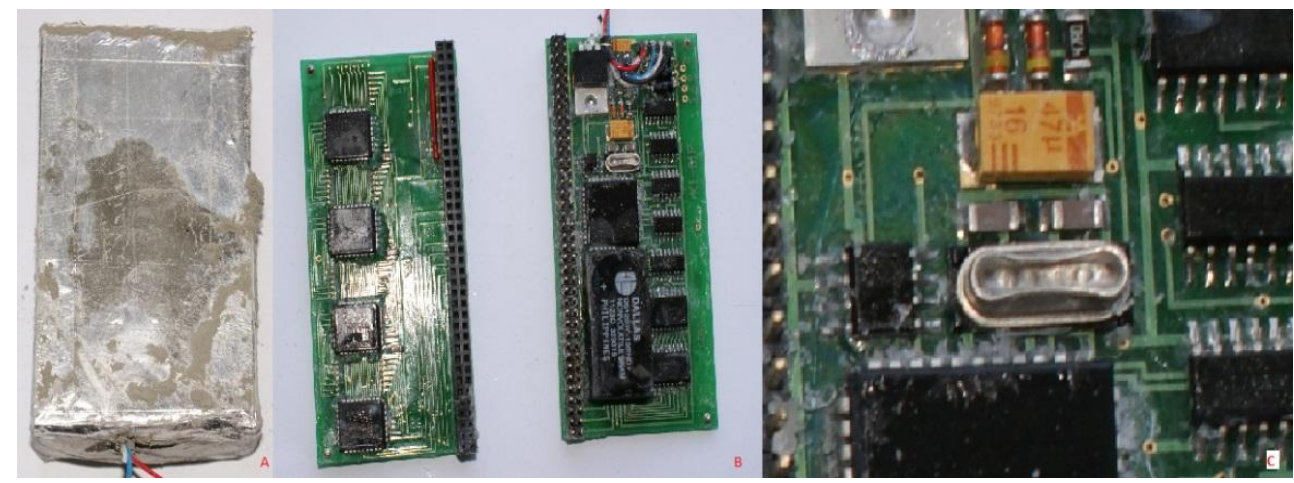

Fig. 30 Status of electronic elements after the pressure test

After pressurisation, the data was read in the same way as prior to testing, using the WTS-5 tester with an installed OAZ decrypting system. We ascertained full indistinguishability of the read data in comparison to the reading conducted prior to placing the catastrophic recorder in the test station chamber. The reading results are presented in table 2. 
Zbigniew Jakielaszek, Grzegorz Kowaleczko, Andrzej J. Panas, Mirostaw Nowakowski

Tab. 2 Values of diagnostic parameters in particular recordings after testing [9]

\begin{tabular}{|c|c|c|c|c|c|c|c|c|c|}
\hline $\begin{array}{c}\text { Recording } \\
\text { name }\end{array}$ & $\begin{array}{c}\text { Recording } \\
\text { date }\end{array}$ & $\begin{array}{c}\text { Start of } \\
\text { recording }\end{array}$ & $\begin{array}{c}\text { Recording } \\
\text { duration }\end{array}$ & Diag & $\mathrm{T}$ & $\begin{array}{c}\text { Model } \\
\text { channel }\end{array}$ & NRID & Vpr & Hbar \\
\hline & D-M-Y & h:m:s & h:m:s & {$[\mathrm{dz}]$} & {$[\mathrm{sec}]$} & {$[\mathrm{dz}]$} & {$[\mathrm{dz}]$} & {$[\mathrm{dz}]$} & {$[\mathrm{dz}]$} \\
\hline 1. & $22-04-14$ & $12: 09: 37$ & $00: 19: 11$ & 0 & $0 \div 1151$ & $2048 \div 2049$ & 696947 & $2049 \div 2050$ & $2557 \div 3581$ \\
\hline 2. & $22-04-14$ & $12: 29: 45$ & $00: 14: 57$ & 0 & $0 \div 897$ & $2048 \div 2049$ & 696947 & $2558 \div 3580$ & $2049 \div 2050$ \\
\hline 3. & $22-04-14$ & $12: 45: 34$ & $00: 14: 58$ & 0 & $0 \div 898$ & $2048 \div 2049$ & 696947 & $2049 \div 2050$ & $2558 \div 3581$ \\
\hline 4. & $22-04-14$ & $13: 01: 08$ & $00: 15: 02$ & 0 & $0 \div 902$ & $2048 \div 2049$ & 696947 & $2557 \div 3581$ & $2049 \div 2050$ \\
\hline 5. & $22-04-14$ & $13: 16: 54$ & $00: 14: 23$ & 0 & $0 \div 863$ & $2048 \div 2049$ & 696947 & $2049 \div 2050$ & $2557 \div 3581$ \\
\hline
\end{tabular}

Testing the catastrophic recorder resistance against exposure to aggressive liquids

The testing of the catastrophic recorder's resistance against exposure to aggressive liquids in accordance with the EuroCAE ED-112 European standard [2] and the defence standard NO-16-A200 [1] is conducted by submerging the catastrophic recorder respectively, for at least 48 hours, in:

- jet fuel,

- oil,

- hydraulic mixture,

- extinguishing agent.

The following extinguishing agents are used:

- aqueous solution of glycol,

- carbon dioxide,

- extinguishing powder,

- extinguishing foam.

The ground testing of the S2-3a recording system's catastrophic recorder featured the use of jet fuels, oil, hydraulic fluids and extinguishing agents used in the Air Force of the Republic of Poland.

The test result is deemed positive if it is possible to recover the test data recorded in the memory of a catastrophic recorder subjected to testing of the resistance against exposure to aggressive liquids.

\section{Summary}

The S2-3a flight parameters recording system's catastrophic recorder meets the strength requirements of the defence standard NO-16-A200 (EuroCAE ED-112), i.e. protects the information recorded in the memory against:

- overloads of 3,400 g within a max. time of $6.5 \mathrm{~ms}$;

- penetration by a metal dowel pin with the diameter of $6.35 \mathrm{~mm}$, weighed down by $227 \mathrm{~kg}$ and falling from $3 \mathrm{~m}$;

- compression with a static force of $22.25 \mathrm{kN}$;

- exposure to temperature of $1,100^{\circ} \mathrm{C}$ in a time exceeding $30 \mathrm{~min}$; 
Testing the catastrophic recorder resistance against the impact of catastrophic... Badania odporności rejestratora katastroficznego na oddziaływanie czynników...

- exposure to deep seawater pressure of $60 \mathrm{MPa}(6,000 \mathrm{~m}$ below the surface level) in the time of $24 \mathrm{~h}$;

- exposure to aggressive liquids.

\section{Literature}

[1] Norma Obronna [Defence Standard] NO-16-A200:2006. Wojskowe statki powietrzne. Pokładowe rejestratory katastroficzne, Wymagania $i$ badania. [Military aircrafts. On-board catastrophic recorders. Requirements and testing.]2006.

[2] EuruCAE ED-112, Minimum operational performance specification for crash protected airbone recorder systems, Revision A September 1. 2013.

[3] Bakalarski J.: Opracowanie obudowy rejestratora parametrów lotu samolotu odpornej na graniczne warunki obciażeń mechanicznych $i$ termicznych [Development of the enclosure for an aircraft's flight parameters recorder, resistant against limit conditions of mechanical and thermal loads]. Warsaw 1993, ITWL no. 10606/I.

[4] Lisiecki J.: Kaseta ochronna [Protective cassette]. PL 16969.

[5] Fiserova D.: Numerical analyses of buried mine explosions with emphasis on effect of soil properties on loading. Cranfield University, 2006.

[6] Lisiecki J., Błażejewicz T., Gmurczyk G.: Stanowisko do badania kasety rejestratora katastroficznego na dziatanie ognia [Catastrophic recorder fire exposure test station]. PL 65757.

[7] Lisiecki J., Błażejewicz T.: Analiza materiałów PCM do zastosowania $w$ kasecie ochronnej pod katem temperatury przemiany [Analysis of the PCM materials for application in the protective cassette in terms of the transition temperature]. ITWL REPORT no. 140/31/2008, 2008.

[8] Report on the paper titled Flight recorder hydrostatic pressurisation station with the pressure of $60 \mathrm{MPa}$ in a seawater environment. IWC PAN 2015.

[9] Report no. 6a/36/2015 from the readings of the S2-3a-K and S2-3a-K/VCR protective cassettes subjected to seawater pressure, according to the ED-112 standard. ITWL 2015. 


\section{BADANIA ODPORNOŚCI REJESTRATORA KATASTROFICZNEGO NA ODDZIAEYWANIE CZYNNIKÓW KATASTROFY}

\section{Wstęp}

Projektowanie i wdrażanie systemów mających zastosowanie w lotnictwie wymaga sprostaniu ściśle określonych norm i przepisów prawa lotniczego. Dokumentem określającym wymagania dla katastroficznych rejestratorów parametrów lotu jest norma obronna NO-16-A200 [1] i norma europejska EuroCAE ED-112 [2]. Przedmiotem badań był rejestrator katastroficzny systemu rejestracji parametrów lotu S2-3a opracowany w Instytucie Technicznym Wojsk Lotniczych. Zarówno układy elektroniczne jak i elementy mechaniczne rejestratorów katastroficznych, zwyczajowo nazywanymi „,czarnymi skrzynkami” są poddawane szeregom testów, weryfikujących ich niezawodność i odporność na oddziaływanie czynników środowiskowych i wytrzymałościowych.

Kryterium klasyfikacyjnym spełnienia wymagań odporności na oddziaływanie czynników katastrofy jest „odzyskiwalność” danych zarejestrowanych w pamięci rejestratora katastroficznego. Dopuszcza się zniekształcenia oraz uszkodzenia mechaniczne i elektryczne rejestratora, przy których możliwe jest odzyskanie zarejestrowanych danych i odtworzenie przebiegów czasowych wszystkich parametrów.

\section{Obiekt badań}

Rejestrator katastroficzny zbudowany jest $\mathrm{z}$ kolejnych elementów, mających zabezpieczyć pakiety pamięci półprzewodnikowych przed narażeniami mechanicznoklimatycznymi jakim może on podlegać w trakcie wypadku lotniczego (katastrofy). Przekrój rejestratora katastroficznego przedstawiono na rys. 1 [3].

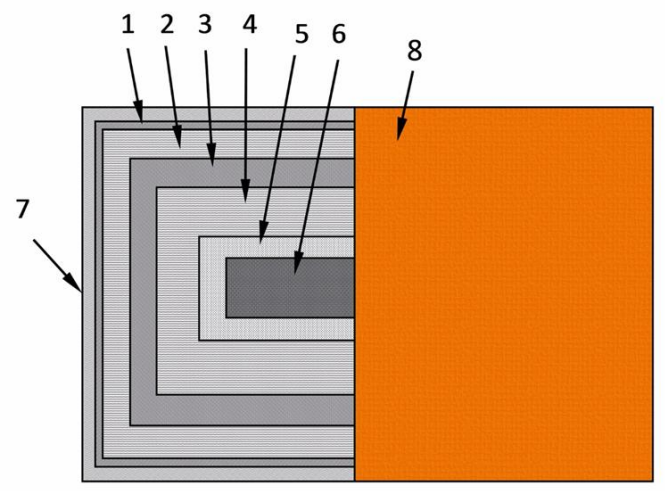

Rys. 1 Rejestrator katastroficzny-przekrój: 1 -obudowa stalowa,

2 - termoizolacyjny materiat mikroporowaty I - wktadka zewnętrzna, 3 - obudowa tytanowa, 4 - termoizolacyjny materiat mikroporowaty II - wktadka wewnętrzna, 5 - elastyczna masa kauczuku silikonowego, 6-pakiety elektroniki, 7 - powtoka ogniochronna, 8-obudowa zewnętrzna 
Testing the catastrophic recorder resistance against the impact of catastrophic... Badania odporności rejestratora katastroficznego na oddziaływanie czynników...

Na powłokę ogniochronną rejestratora katastroficznego zastosowano pęczniejącą farbę ogniochronną rozpuszczalnikową Flame Stal (FS), zbrojoną siatką z włókna szklanego. Widok rejestratora katastroficznego przedstawiono na rys. 2.

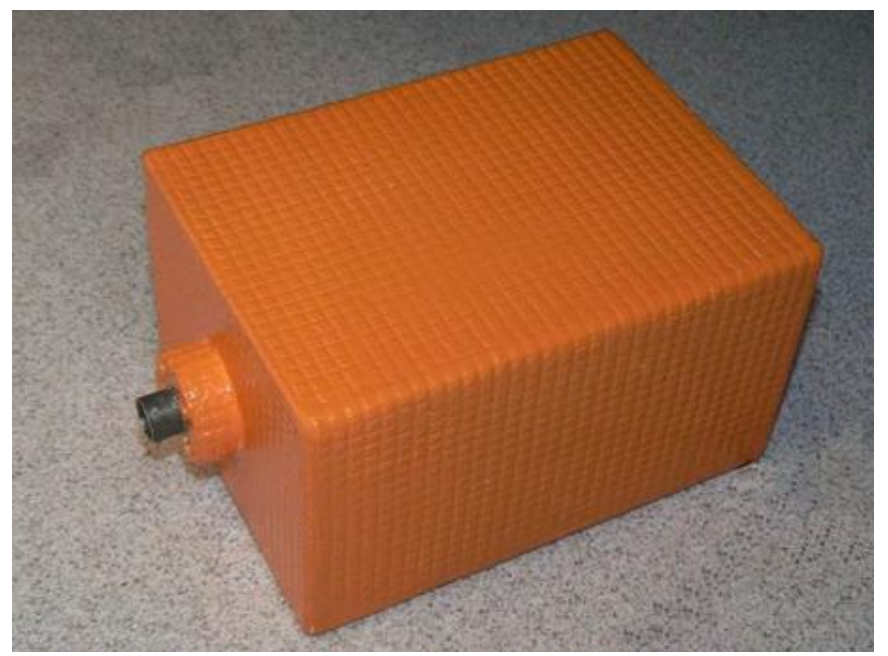

Rys. 2 Rejestrator katastroficzny [4]

\section{Zakres badań}

Badania odporności na oddziaływanie czynników katastrofy lotniczej obejmują serię badań symulujących narażenia, które mogą wystąpić podczas katastrofy lotniczej. Przed rozpoczęciem badań w pamięci umieszczonej wewnątrz rejestratora katastroficznego należy zarejestrować dane testowe. W czasie badań dopuszczalna jest tylko kontrola zawartości pamięci (nie dopuszcza się odświeżania danych oraz demontażu lub naprawy elementów konstrukcji). Badania odporności na oddziaływanie czynników katastrofy lotniczej obejmują następujące czynniki $[1,2]$ :

a) przeciążenie występujące przy zderzeniu $3400 \mathrm{~g}$ przez około $6,5 \mathrm{~ms}$;

b) przebicie stalowym cylindrycznym trzpieniem o średnicy $6,35 \mathrm{~mm}$ i masie $227 \mathrm{~kg}$ spadającym z wysokości $3 \mathrm{~m}$;

c) ściskanie statyczne siłą $22 \mathrm{kN}$ przez $5 \mathrm{~min}$;

d) ogień o strumieniu cieplnym $158 \mathrm{~kW} / \mathrm{m}^{2}$, temperaturze $1100{ }^{\circ} \mathrm{C} \mathrm{w}$ czasie narażenia co najmniej $30 \mathrm{~min}$;

e) ciśnienie pod powierzchnią wody $60 \mathrm{MPa}(6000 \mathrm{~m})$ przez co najmniej 24 godziny;

f) ciecze agresywne (olej, paliwa, słona woda).

W trakcie badań wymagane jest zachowanie kolejności badań wyszczególnionych w punktach od a do f. 


\section{Badanie odporności rejestratora katastroficznego na przeciążenie występujące przy zderzeniu}

Badanie odporności na przeciążenie występujące przy zderzeniu polega na poddaniu rejestratora katastroficznego oddziaływaniu przeciążenia sinusoidalnego o amplitudzie $33354 \mathrm{~m} / \mathrm{s}^{2}(3400 \mathrm{~g}$ ) w czasie trwania połowy jego okresu równym 6,5 ms. Zamiast przeciążenia sinusoidalnego dopuszcza się oddziaływanie ekwiwalentnego przeciążenia trapezoidalnego o przebiegu przedstawionym na rys. 3 .

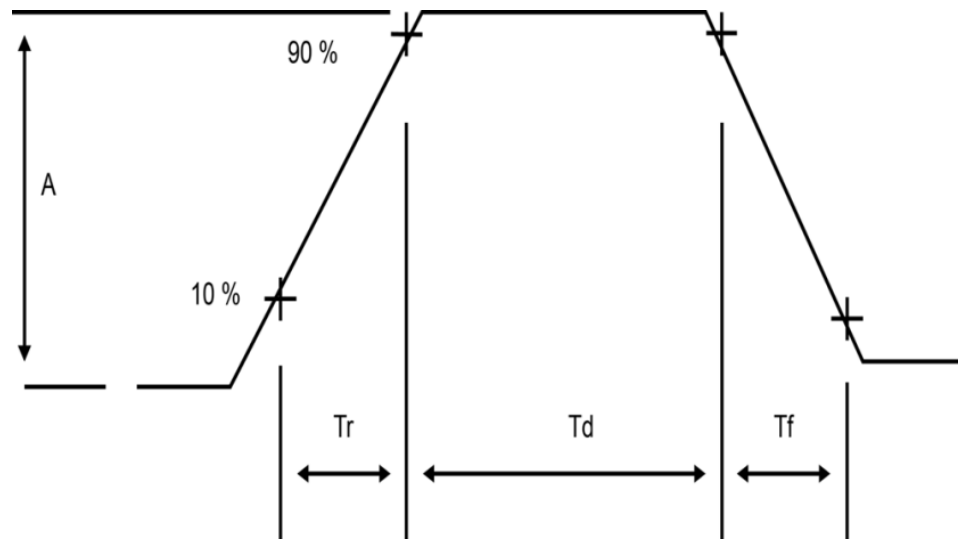

Rys. 3 Przebieg ekwiwalentnego przeciązenia trapezoidalnego oddziaływujacego na rejestrator katastroficzny: $A=3400 \mathrm{~g}\left(33354 \mathrm{~m} / \mathrm{s}^{2}\right)$ minimum, $T_{r}=3,5 \mathrm{~ms}$ maksimum, $T_{d}=3,0 \mathrm{~ms}$ minimum, $T_{f}>0,0 \mathrm{~ms}$

W badaniu mającym wykazać spełnienie wymagania odporności rejestratora katastroficznego na przeciążenie 3400 g można wyróżnić dwa podstawowe zagadnienia:

- rozpędzanie obiektu do prędkości, przy której możliwe będzie osiągnięcie wymaganego przeciążenia;

- hamowanie obiektu zgodnie z wymaganą charakterystyką.

$\mathrm{Z}$ racji braku dostępu do urządzeń wskazanych $\mathrm{w}$ normie została opracowana metoda wymuszenia i pomiaru wymaganych przeciążeń $w$ oparciu o działo pneumatyczne. Wybrano działo pneumatyczne DPZ-250 w Instytucie Lotnictwa, którego charakterystyka pozwala na badanie obiektów o masie do $15 \mathrm{~kg}$.

Do hamowania obiektu badań wybrano przeszkodę złoża piasku.

Aby uzyskać pożądaną wartość przeciążeń należy zatrzymać obiekt poruszający się z prędkością $520 \mathrm{~km} / \mathrm{h}$ na drodze $0,23 \mathrm{~m}$. Interpretację fizyczną wymagań testu przedstawia rys. 4 . 
Testing the catastrophic recorder resistance against the impact of catastrophic... Badania odporności rejestratora katastroficznego na oddziaływanie czynników...

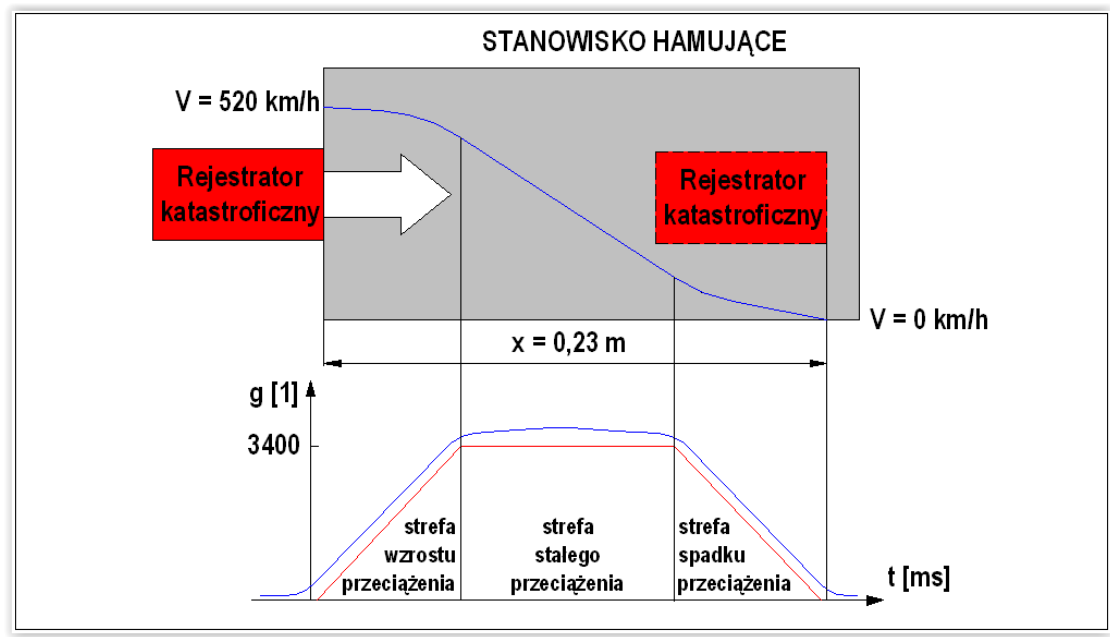

Rys. 4 Interpretacja fizyczna wymagań testu

$\mathrm{Z}$ punktu widzenia prowadzenia badań najbardziej istotna jest zmiana prędkości przemieszczania się obiektu badań $\mathrm{w}$ przyjętym środowisku stanowiska hamującego jakim jest piasek. Ciężar właściwy piasku ma podstawowy wpływ na dynamikę zmian prędkości obiektu badań. Charakterystyka porównawcza zmian prędkości w czasie w zależności od gęstości piasku przedstawiona została na rys. 5 . Do porównania przyjęto gęstość piasku:

- dla przebiegu symulowanego zgodnie z propozycją D. Fiserovej [5],

- dla przebiegu symulowanego zgodnie z bazą programu ANSYS AUTODYN,

- dla przebiegu eksperymentalnego.

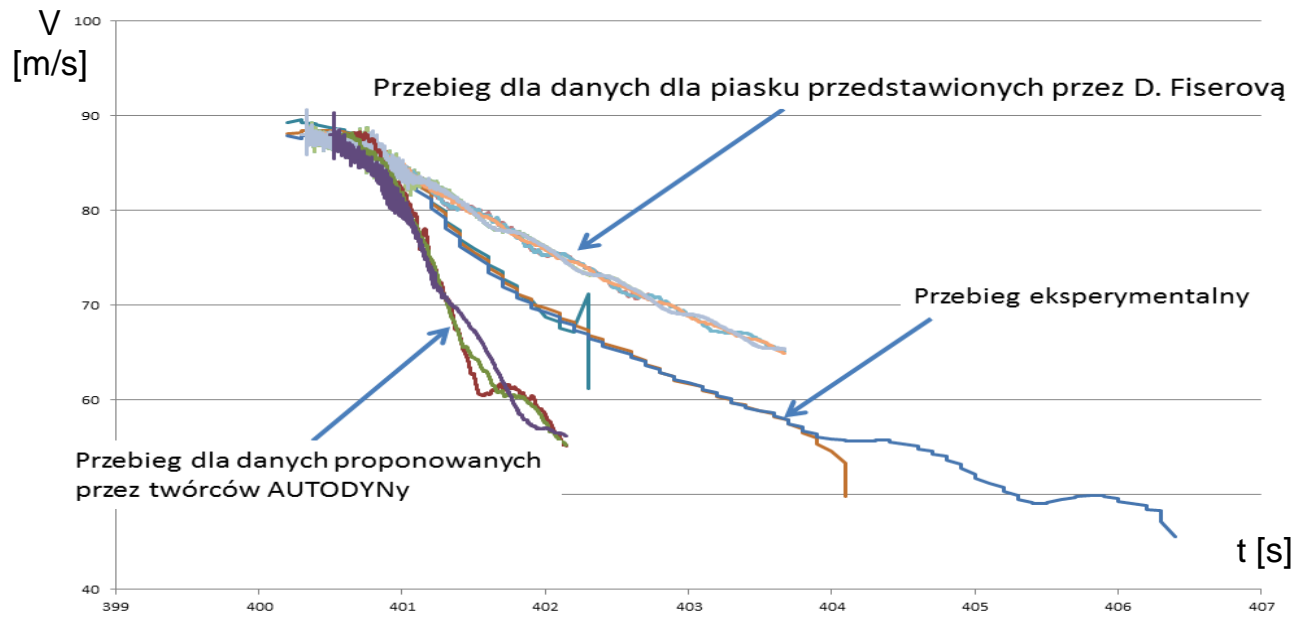

Rys. 5 Charakterystyka zmian prędkości w czasie w zależności od gęstości piasku

Elementami wchodzącymi w skład realizowanego eksperymentu są: 
- działo pneumatyczne - stanowisko napędzające obiekt badań;

- sonda badawcza - element pozwalający na zabudowę właściwego obiektu badań tzn. pakietu elektroniki rejestratora katastroficznego;

- stanowisko hamujące - element zapewniający zatrzymanie obiektu badań;

- kamera do rejestracji procesów szybkozmiennych;

- rejestrator do rejestracji udarów (umieszczony w sondzie badawczej) - opcja;

- czujniki do pomiaru udarów (umieszczone w sondzie badawczej) - opcja;

- reflektory oświetlające strefę strzałów.

Schemat stanowiska pomiarowego przedstawiono na rys. 6 .

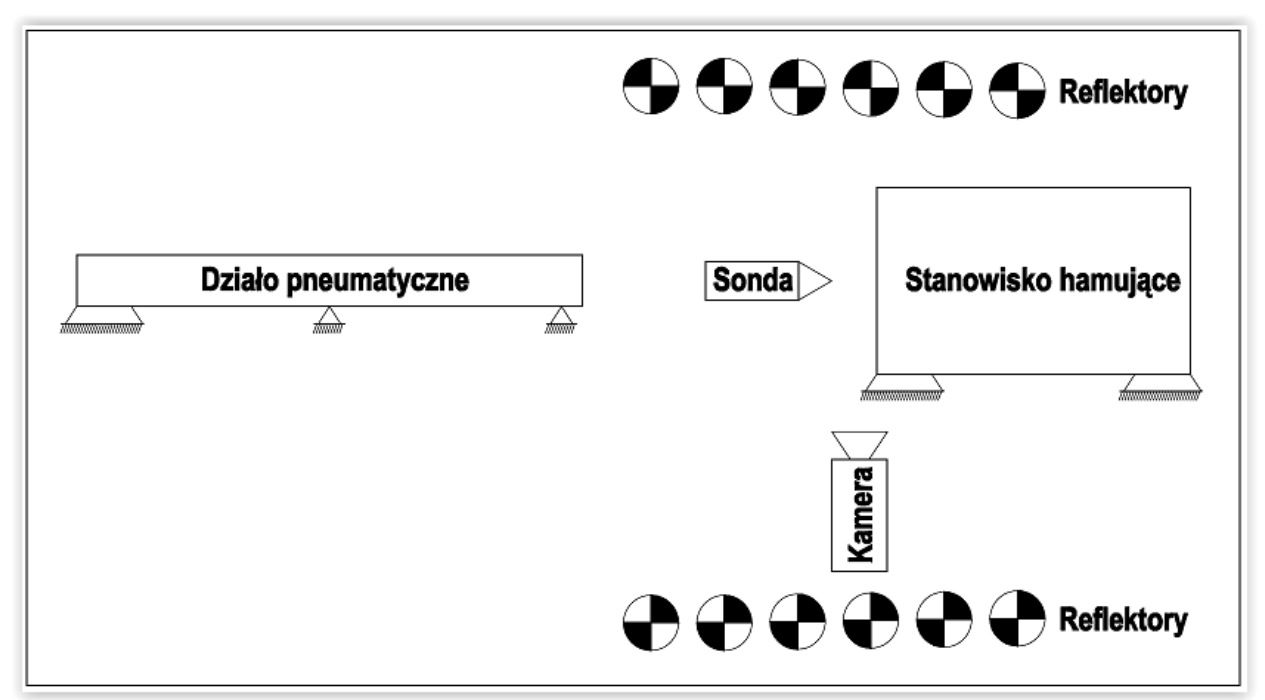

Rys. 6 Schemat stanowiska pomiarowego

Istotą wykorzystania działa jest nadanie prędkości obiektowi badań. Do nadania wymaganej prędkości obiektu badań wykorzystano działo pneumatyczne DPZ-250. Podstawowe dane techniczne działa DPZ-250:

- średnica lufy $-250 \mathrm{~mm}$;

- długość lufy - 8 m;

- masa maksymalna obiektu badań - $15 \mathrm{~kg}$;

- masa minimalna obiektu badań - $0,9 \mathrm{~kg}$;

- prędkość obiektu badań dla masy maksymalnej - $180 \mathrm{~m} / \mathrm{s}$;

- prędkość obiektu badań dla masy minimalnej - $310 \mathrm{~m} / \mathrm{s}$;

- maksymalne ciśnienie - 10 bar.

Podstawową informacją przy wykorzystaniu działa jest masa wystrzeliwanego obiektu i wymagana prędkość lotu obiektu po opuszczeniu lufy. Kluczowe znaczenie w wykorzystaniu działa ma znajomość zależności $V=f(p)$ czyli prędkości wylotowej działa do ciśnienia powietrza użytego do strzału. Widok działa DPZ-250 przedstawiono na rys. 7. 
Testing the catastrophic recorder resistance against the impact of catastrophic... Badania odporności rejestratora katastroficznego na oddziaływanie czynników...

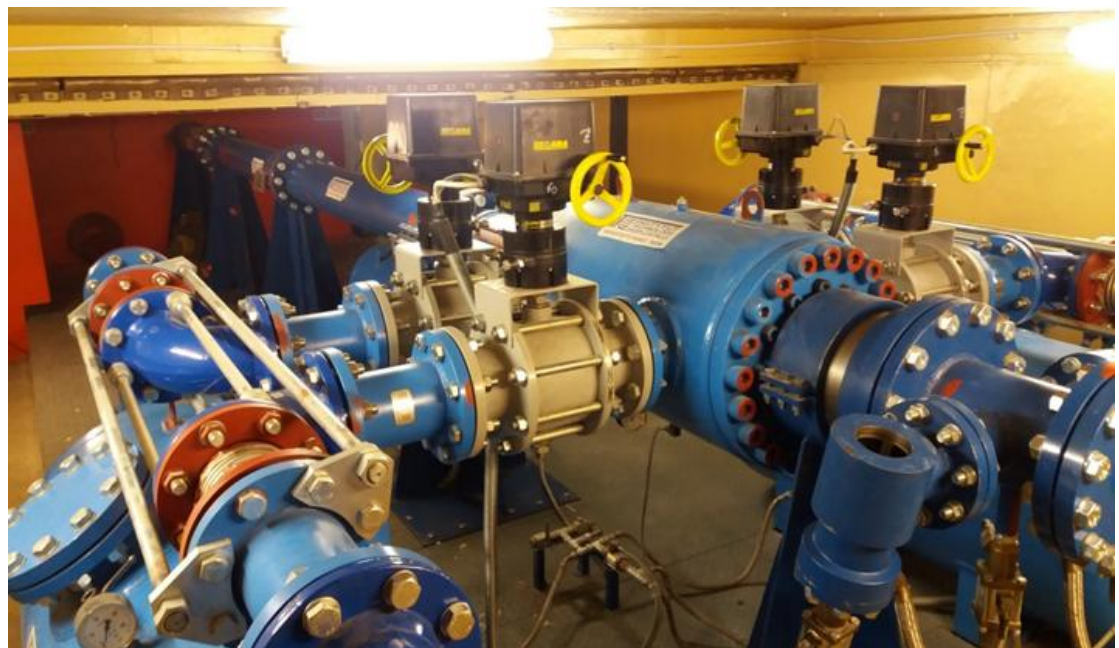

Rys. 7 Dziato pneumatyczne DPZ 250 (Instytut Lotnictwa)

Charakterystykę $V=f(p)$ dla wybranych mas obiektów badań przedstawiono na rys. 8 .

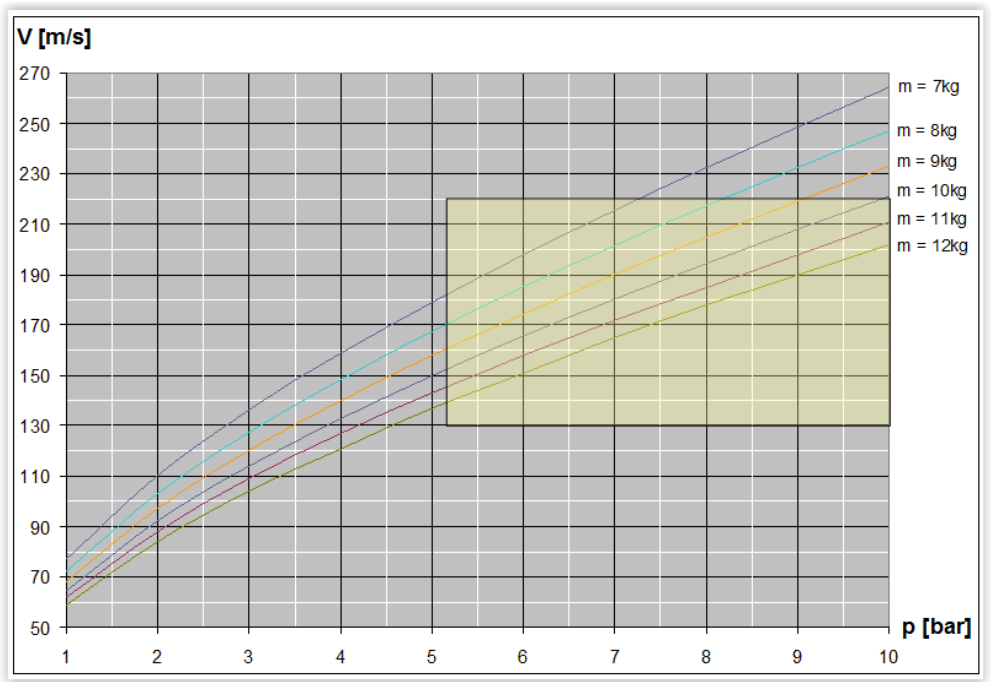

Rys. 8 Charakterystyka $V=f(p)$ działa pneumatycznego DPZ-250

Obiektem badań do określenia parametrów testu zderzeniowego rejestratora katastroficznego była sonda badawcza. W poszczególnych etapach badań stosowano sondy o różnych kształtach. Na początku były to wykonane ze stali ekwiwalenty odpowiednio masowy i gabarytowy rejestratora katastroficznego oraz masowy umożliwiający montaż rejestratora udarów. Widok pierwszych sond pomiarowych przedstawiono na rys. 9 . 
Zbigniew Jakielaszek, Grzegorz Kowaleczko, Andrzej J. Panas, Mirostaw Nowakowski

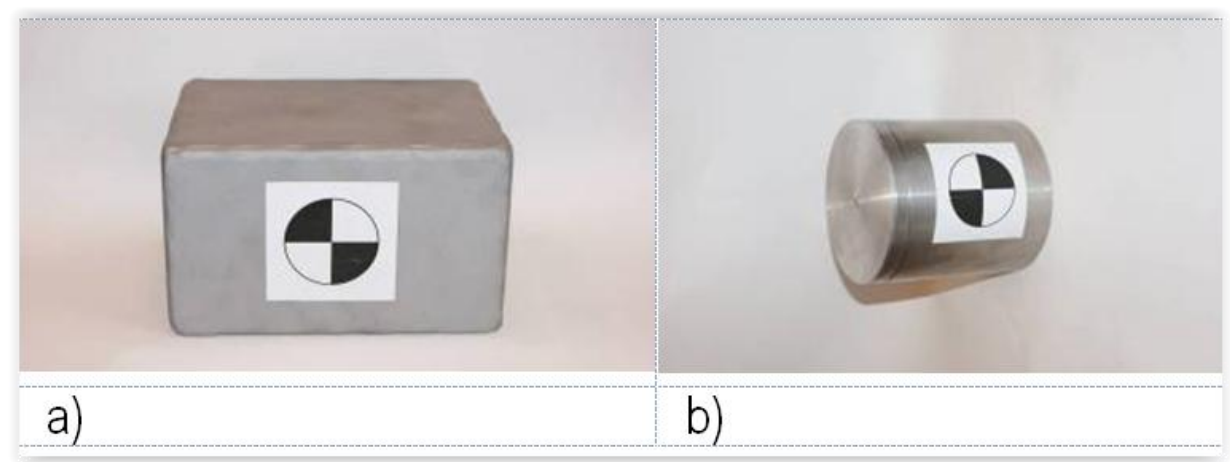

Rys. 9 Widok sond pomiarowych: a) ekwiwalent masowy i gabarytowy;

b) ekwiwalent masowy dostosowany do zabudowy rejestratora

W następnym etapie wykorzystano sondy, w których zastosowano w przedniej części stożkowo ścięte penetratory o kącie rozwarcia $90^{\circ}$ i $60^{\circ}$ o różnych masach i długościach. Widok sond z korpusem z poliacetalu przedstawiono na rys. 10.

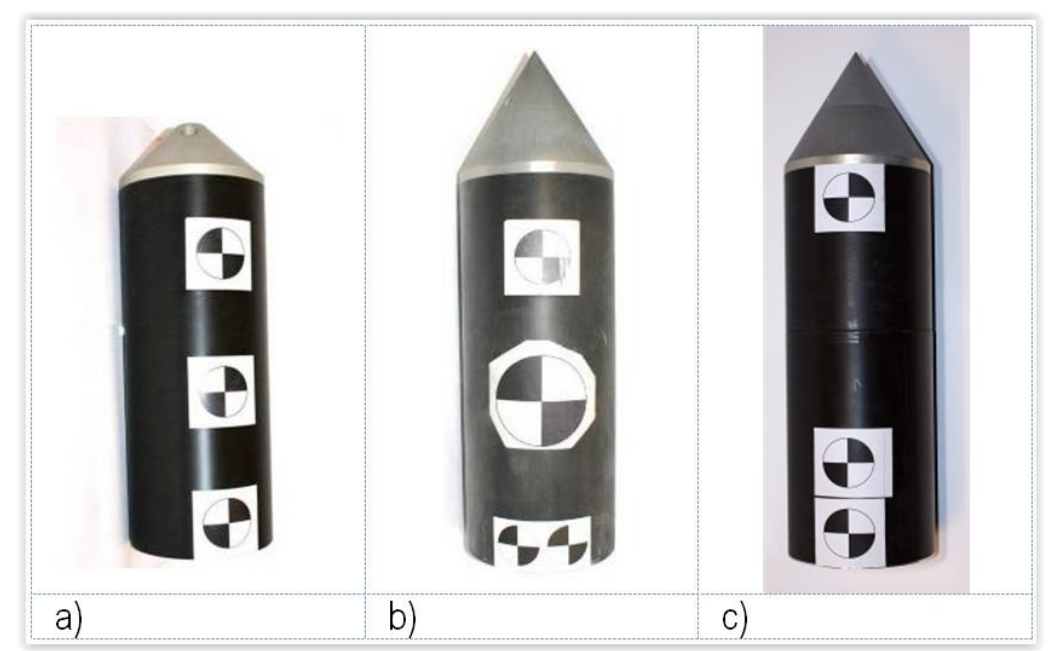

Rys. 10 Widok sond pomiarowych z korpusem z poliacetalu:

a) sonda z penetratorem o kacie rozwarcia $90^{\circ}$, b) sonda z penetratorem o kacie rozwarcia $60^{\circ}$, c) sonda z penetratorem o kacie rozwarcia $60^{\circ} i$ korpusem $z$ drążona przestrzenia na pakiet elektroniki

W ostatnim etapie badań wykorzystywane były sondy o długościach: $641 \mathrm{~mm}$ i $846 \mathrm{~mm}$ z penetratorem o kącie rozwarcia $60^{\circ} \mathrm{z}$ oznaczeniem „średnia” i „długa”, wykonane z duralu Pa-9. Schemat budowy sondy oraz widok ,średniej” i „długiej” sondy przedstawiono na rys. 11 . 
Testing the catastrophic recorder resistance against the impact of catastrophic... Badania odporności rejestratora katastroficznego na oddziaływanie czynników...

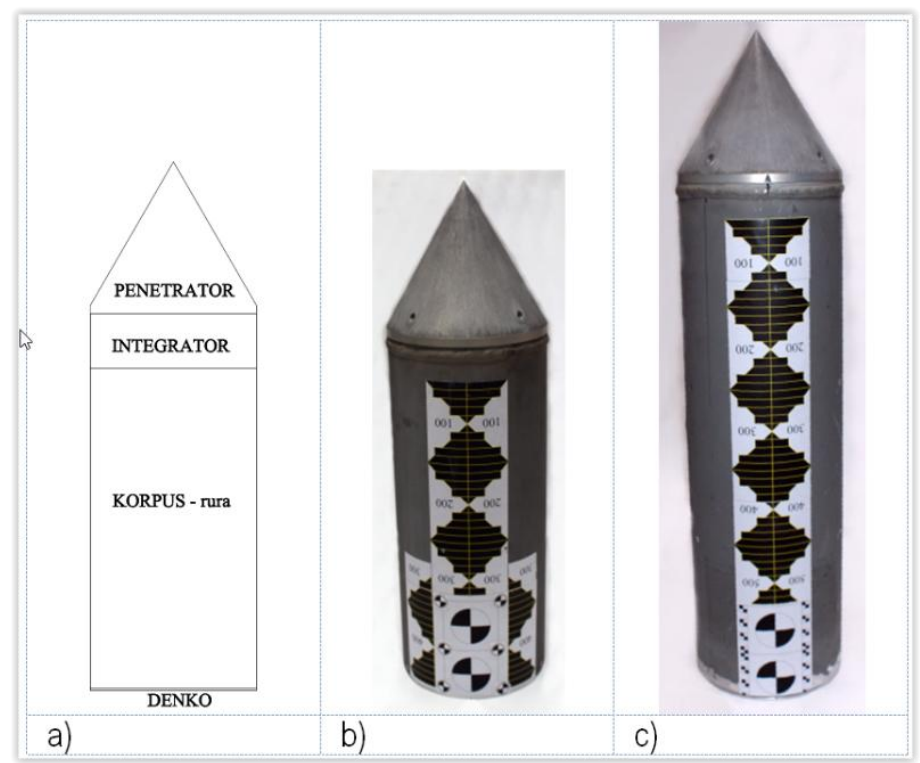

Rys. 11 Widok sond pomiarowych wykonanych z duralu:

a) opis elementów składowych sondy, b) „, średnia” sonda, c) „,dtuga” sonda

$\mathrm{W}$ związku $\mathrm{z}$ trudnościami $\mathrm{z}$ wykorzystaniem niezależnego systemu rejestracji zaistniała potrzeba rejestracji całego testu za pomocą kamery PHANTOM V711. W związku z powyższym zaprojektowano „średnią” i „długą” sondę pomiarową. „Długa" sonda przewidziana jest do zapewnienia zapisu o odpowiedniej długości trwania natomiast „średnia”, przy zachowaniu identycznej masy, zapewnia zabudowę pakietu elektroniki z rejestratora katastroficznego. Pakiet elektroniki umieszczono $\mathrm{w}$ osłonie materiału termoizolacyjnego $\mathrm{w}$ obudowie imitującej tytanową obudowę z rejestratora katastroficznego. W pamięci pakietu elektroniki zapisano przebieg testowy. Ponieważ sondy miały identyczną masę, to wystrzeliwano je dla tych samych ciśnień ładowania działa.

Dane dotyczące testu z wykorzystaniem ,średniej” sondy:

- długość sondy: $641 \mathrm{~mm}$;

- masa sondy: 8,905 kg;

- całkowita masa pocisku: $11,455 \mathrm{~kg}$;

- ciśnienie robocze działa pneumatycznego: 9,5 bar.

Dane dotyczące testu z wykorzystaniem ,długiej” sondy:

- długość sondy: $846 \mathrm{~mm}$;

- masa sondy: $8,9 \mathrm{~kg}$;

- całkowita masa pocisku: $11,5 \mathrm{~kg}$;

- ciśnienie robocze działa pneumatycznego: 9,5 bar. 
Zbigniew Jakielaszek, Grzegorz Kowaleczko, Andrzej J. Panas, Mirostaw Nowakowski

Przebieg badań rejestrowano za pomocą kamery do szybkozmiennych zjawisk typu PHANTOM V711 umożliwiającej rejestrację obrazu z prędkością 24000 klatek/s z rozdzielczością 1280x240. Przykłady rejestracji przedstawiono na rys. 12.

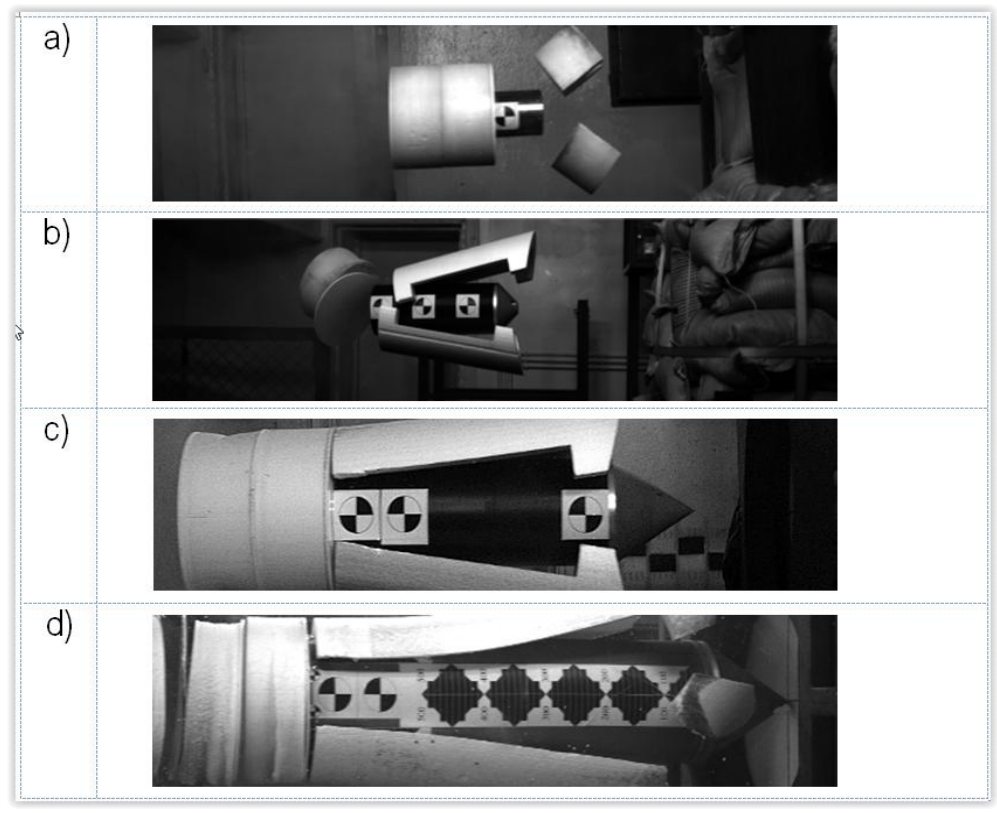

Rys. 12 Widok przykladowych sond w ostatniej fazie lotu: a) ekwiwalent masy, b) sonda z poliacetalu z penetratorem o kacie rozwarcia 90, c) drażona sonda z poliacetalu z penetratorem o kacie rozwarcia $\left.60^{\circ}, d\right)$, dhoga" sonda z duralu z penetratorem o kacie rozwarcia $60^{\circ}$

Celem badań było uzyskanie informacji o wartości przeciążenia i czasie trwania zjawiska zderzenia sondy pomiarowej $\mathrm{z}$ przeszkodą. W celu zatrzymania sondy w porównywalnych warunkach zastosowano przeszkodę złoża piasku. Do pierwszych, rozpoznawczych testów wykorzystana była pryzma ułożona z worków wypełnionych piaskiem. Widok pierwotnego stanowiska hamującego przedstawiono na rys. 13.

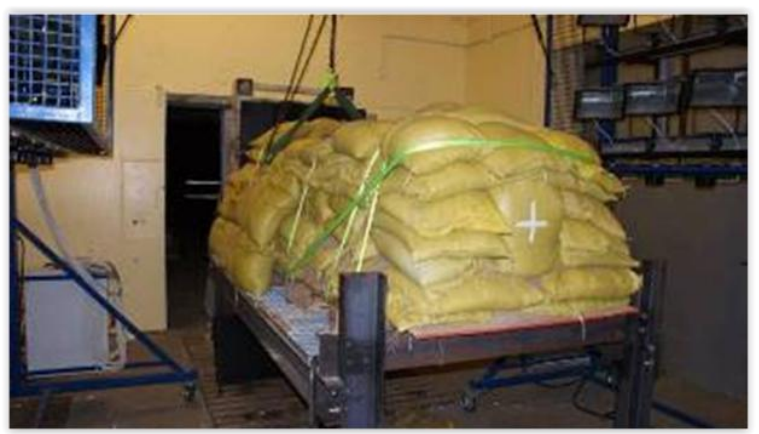

Rys. 13 Widok pierwotnego stanowiska hamujacego 
Testing the catastrophic recorder resistance against the impact of catastrophic... Badania odporności rejestratora katastroficznego na oddziaływanie czynników...

W końcowej fazie, do testów z dużą prędkością uderzenia opracowano stanowisko hamujące $\mathrm{w}$ postaci pojemnika na piasek, składającego się z pięciu segmentów odpowiednio wzmocnonych. Widok stanowisk hamujących przedstawiono na rys. 14 .

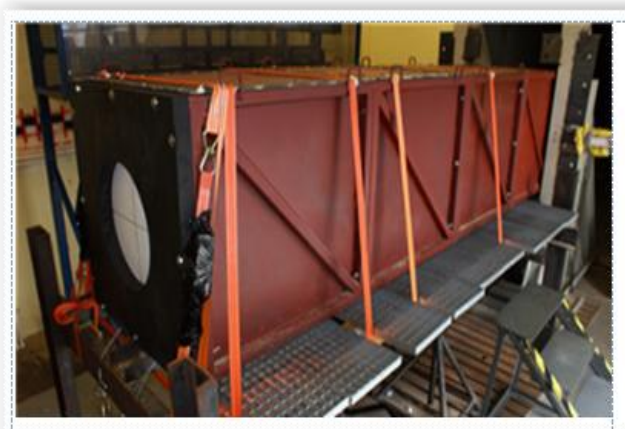

a)

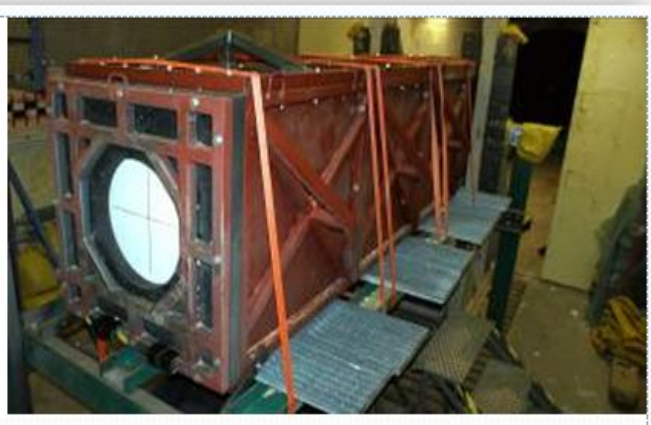

b)

Rys. 14 Widok stanowiska hamujacego w postaci pojemnika na piasek: a) poczatkowe rozwiazanie pojemnika na piasek, b) końcowa, wzmocniona wersja stanowiska hamujacego

Przebieg zmian prędkości po zetknięciu sond ze stanowiskiem hamującym dla sondy „średniej” i „długiej” przedstawiono rys. 15.

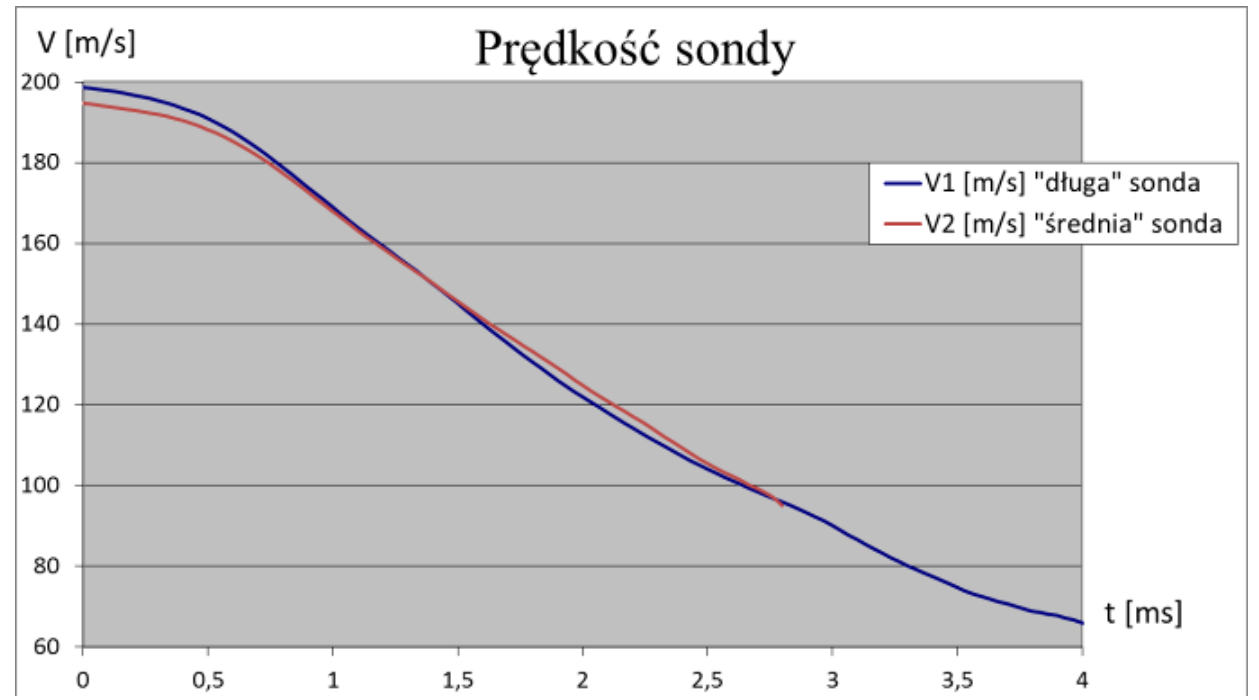

Rys. 15 Przebieg zmian prędkości hamowania sond

Obliczony na tej podstawie przebieg zmian przyspieszenia oraz przyspieszenia normatywne przedstawiono na rys. 16. 


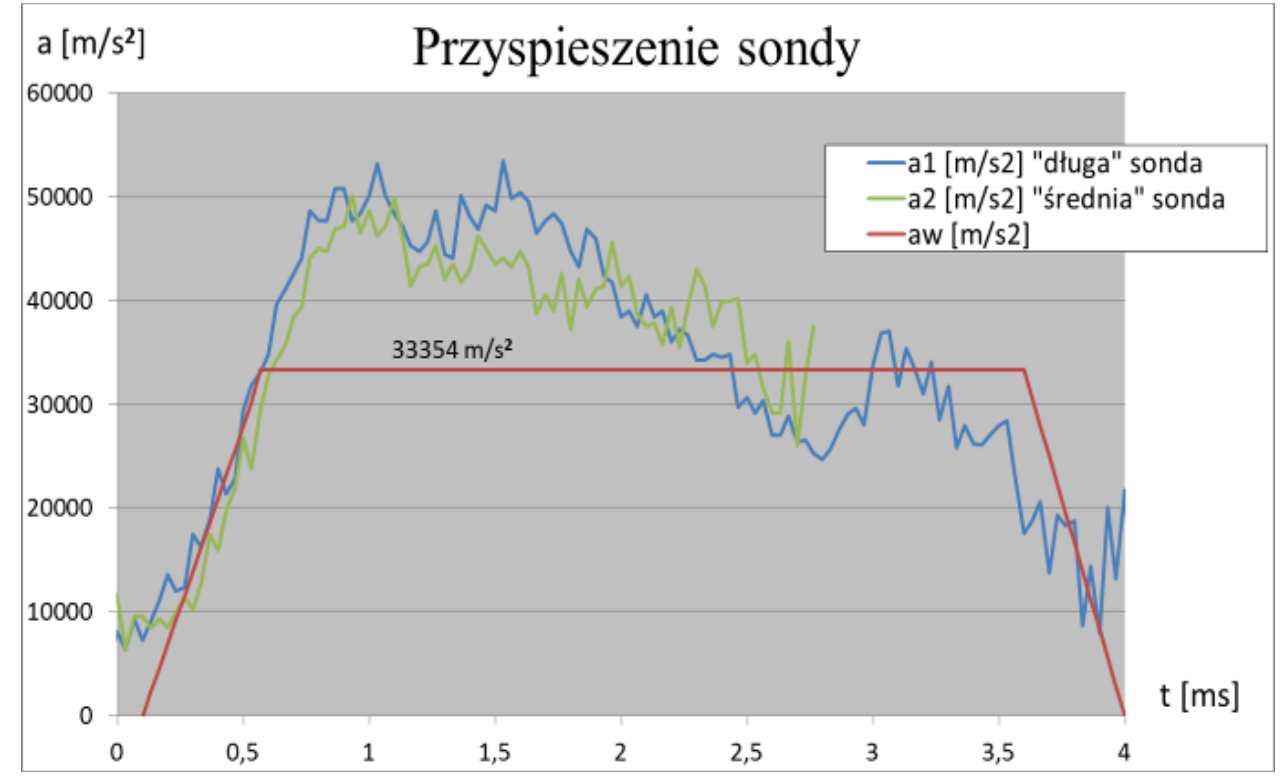

Rys. 16 Przebieg zmian przyspieszenia sond w odniesieniu do wymaganego impulsu

Uzyskana wartość przyspieszenia jest większa od wymaganej przez ponad 2,5 ms i nieznacznie mniejsza $w$ końcowych fragmentach rejestracji, w przedziale od 2,5 $\mathrm{ms}$ do 3,0 ms i powyżej 3,3 ms. Wynik ten uzyskano przy granicznych możliwościach działa dla użytej masy sond pomiarowych.

W trakcie realizacji badania określenia charakterystyki zderzeniowej rejestratora katastroficznego potwierdzono skuteczność przyjętej metodyki i procedur mających na celu ustalenie zachowania się obiektu badań podczas hamowania w przeszkodzie z piasku.

Wykorzystane dwukrotnie, podczas testów, pakiety elektroniki rejestratora katastroficznego zachowały zapisane dane, które z powodzeniem odtworzono.

W doświadczeniach nie udało się dokładnie odtworzyć warunków opisanych w normie, jednak zarówno większe wartości prędkości początkowej, jak i przebieg przyspieszeń podczas hamowania dowodzą, że ilości rozpraszanej energii są większe niż wymagane normą. Można zatem stwierdzić, że narażenia testu były większe od wymaganych. Analiza danych wykonanych eksperymentów wskazuje jednak na to, że z pomocą działa pneumatycznego, przy niewielkich zmianach konstrukcyjnych sondy badawczej, możliwe będzie osiągniecie wymaganej charakterystyki wyhamowania testowanego obiektu. 
Testing the catastrophic recorder resistance against the impact of catastrophic... Badania odporności rejestratora katastroficznego na oddziaływanie czynników...

\section{Badanie odporności rejestratora katastroficznego na przebicie}

Badanie polega na przebiciu rejestratora katastroficznego stalowym cylindrycznym trzpieniem o średnicy $(6,35 \pm 0,1) \mathrm{mm}$, długość wystającej końcówki $(40 \pm 1) \mathrm{mm}$, twardości od 39 HRC do 45 HRC, z obciążnikiem o masie $227 \mathrm{~kg}$, spadającym $\mathrm{z}$ wysokości $3 \mathrm{~m}$.

Stanowisko do badania rejestratora na odporność na przebicie trzpieniem przedstawiono na rys. 17 .

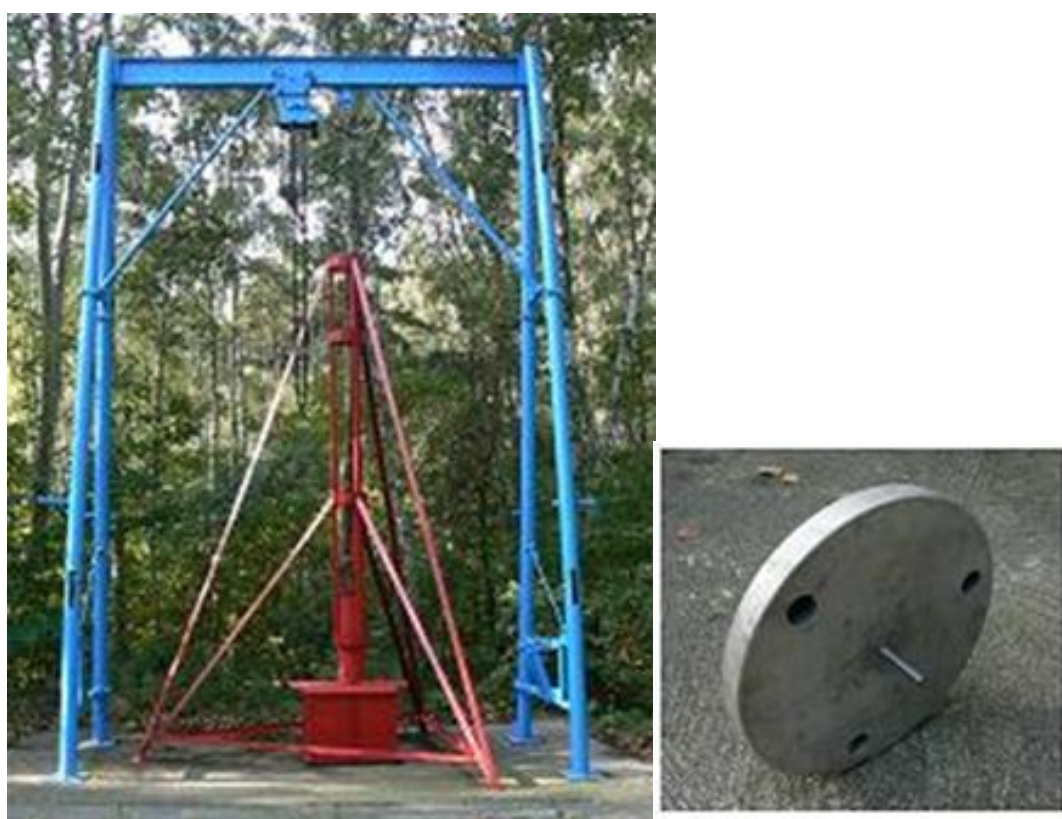

Rys. 17 Stanowisko do badania rejestratora na odporność na przebicie trzpieniem

Zgodnie z normą obronną badanie odporności rejestratora katastroficznego na przebicie, spowodowane uderzeniem nie przekroczyło $20 \%$ początkowej objętości rejestratora.

\section{Badanie odporności rejestratora katastroficznego na ściskanie statyczne}

Badanie polega na poddaniu rejestratora katastroficznego jednoosiowemu ściskaniu statycznemu siłą liniowo rosnącą do $22 \mathrm{kN}$, która po osiągnięciu maksymalnej wartości oddziaływała na kasetę przez $5 \mathrm{~min}$. Badanie przeprowadza się z wykorzystaniem prasy hydraulicznej, w której do pomiaru siły nacisku wykorzystuje się manometr, mierzący ciśnienie cieczy (rys. 18). Rejestrator katastroficzny podpiera się $\mathrm{w}$ osi nacisku okrągłymi, sprężystymi podkładkami o średnicy $5 \mathrm{~cm}$ i grubości $1,25 \mathrm{~cm}$. 


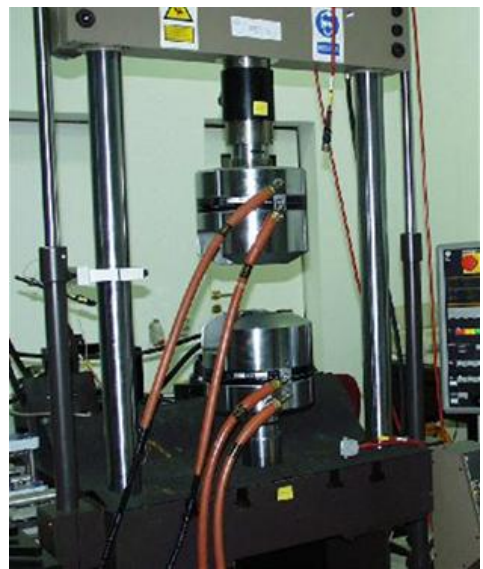

Rys. 18 Stanowisko do badania odporności rejestratora katastroficznego na ściskanie statyczne

Badanie odporności rejestratora katastroficznego na ściskanie statyczne uznaje się za pozytywne, gdy po usunięcia obciążenia ugięcia wywołane oddziaływaniem siły ustąpią a zapisana informacja testowa została zachowana w całości.

\section{Badanie odporności rejestratora katastroficznego na oddziaływanie ognia}

Zgodnie z normą NO-16-A200, od rejestratora katastroficznego w zakresie odporności na pożar wymaga się odzyskania całości zapisanych w pamięci danych po wykonaniu próby w następujących warunkach:

- ogień o minimalnym strumieniu cieplnym wynoszącym $158 \mathrm{~kW} / \mathrm{m}^{2}$;

- minimalna temperatura płomienia $1100{ }^{\circ} \mathrm{C}$, mierzona w odległości $25 \mathrm{~mm}$ od powierzchni rejestratora;

- czas narażenia na działanie ognia całej zewnętrznej powierzchni rejestratora co najmniej 30 minut w sposób nieprzerwany;

- chłodzenie rejestratora po badaniu w sposób naturalny do temperatury otoczenia.

Rejestrator katastroficzny na stanowisku badawczym przedstawiono na rys. 19.

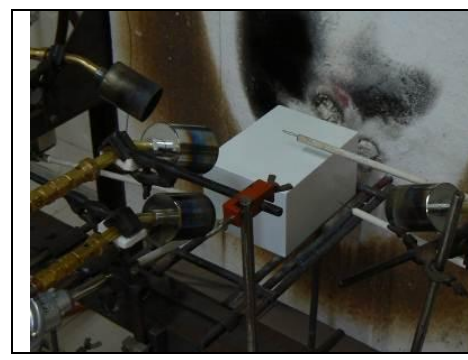

a)

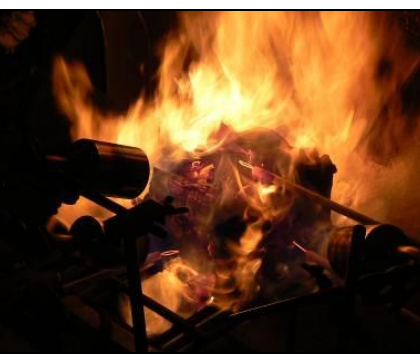

b)

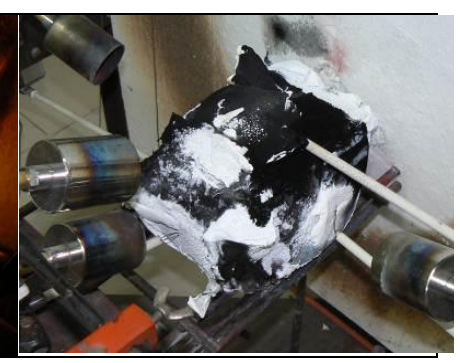

c)

Rys. 19 Widok rejestratora katastroficznego na stanowisku badawczym:

a) przed próba, b) w trakcie próby, c) po próbie [6] 
Testing the catastrophic recorder resistance against the impact of catastrophic... Badania odporności rejestratora katastroficznego na oddziaływanie czynników...

Przykładowe wyniki z badania rejestratora katastroficznego pokrytej powłoka ogniochronną o grubości około $2 \mathrm{~mm}$, wykonaną z farby rozpuszczalnikowej Flame Stal zbrojonej siatką $\mathrm{z}$ włókna szklanego, $\mathrm{z}$ wkładką termoizolacyjną z materiału mikroporowatego o grubości $15 \mathrm{~mm}$, w której umieszczono kasetę pancerną a w niej moduł elektroniczny z zapisaną informacją testową wypełnioną elastyczną masą z kauczuku silikonowego przedstawiono na rys. 20.

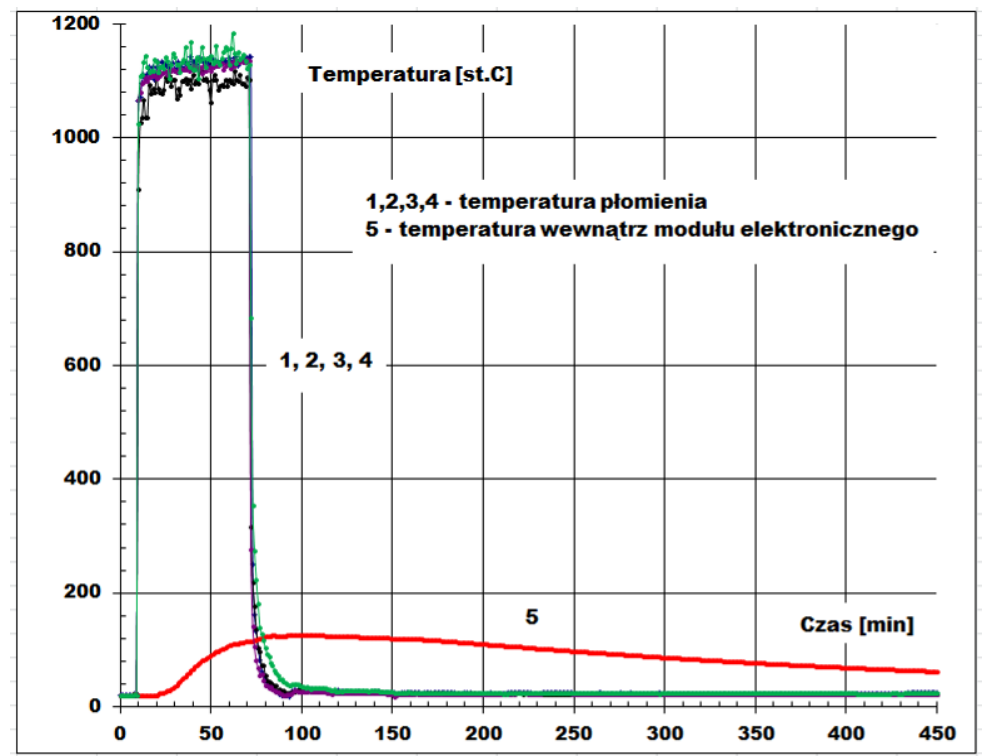

Rys. 20 Zależność temperatury wewnątrz rejestratora katastroficznego i temperatury płomieni od czasu [7]

Z przeprowadzonych badań rejestratora katastroficznego w zakresie odporności na oddziaływanie ognia wynika, że zapisana informacja testowa została zachowana w całości. Zapisana informacja przetrwała godzinna próbę w ogniu o temperaturze $1100^{\circ} \mathrm{C}$. Temperatura wewnątrz rejestratora katastroficznego dla modułu elektronicznego była $\leq 130^{\circ} \mathrm{C}$.

\section{Badanie odporności rejestratora katastroficznego na ciśnienie pod powierzchnią wody}

Badanie polega na poddaniu procesowi ciśnieniowania rejestratora lotu w warunkach symulujących zanurzenie w środowisku wody morskiej na głębokości $6 \mathrm{~km}$, co odpowiada ciśnieniu $60 \mathrm{MPa}$, działającego na rejestrator katastroficzny w czasie 24 godzin. Kluczowym czynnikiem przy zaprojektowaniu komory badawczej do ciśnieniowania rejestratora było określenie ściśliwości medium, w którym zanurzony był rejestrator katastroficzny.

Ściśliwość wody morskiej, tj. jej podatność na odkształcenie objętościowe przy zmianie ciśnienia oparto o badania $\mathrm{w}$ specjalnym urządzeniu doświadczalnym pozwalającym na określenie ściśliwości wody, a także wodnych roztworów soli $\mathrm{NaCl}[8]$. 
$\mathrm{Na}$ podstawie przeprowadzonych badań laboratoryjnych, obliczono zmiany objętości wodnych roztworów $\mathrm{NaCl}$, względem ich objętości początkowej $(\Delta V / V)$ wyrażone $\mathrm{w}$ procentach oraz określono współczynnik ściśliwości $\beta$. Charakterystyki zachodzących zmian objętości i współczynników ściśliwości pod wpływem ciśnienia dla badanych roztworów przedstawiono na rys. 21 i rys. 22.

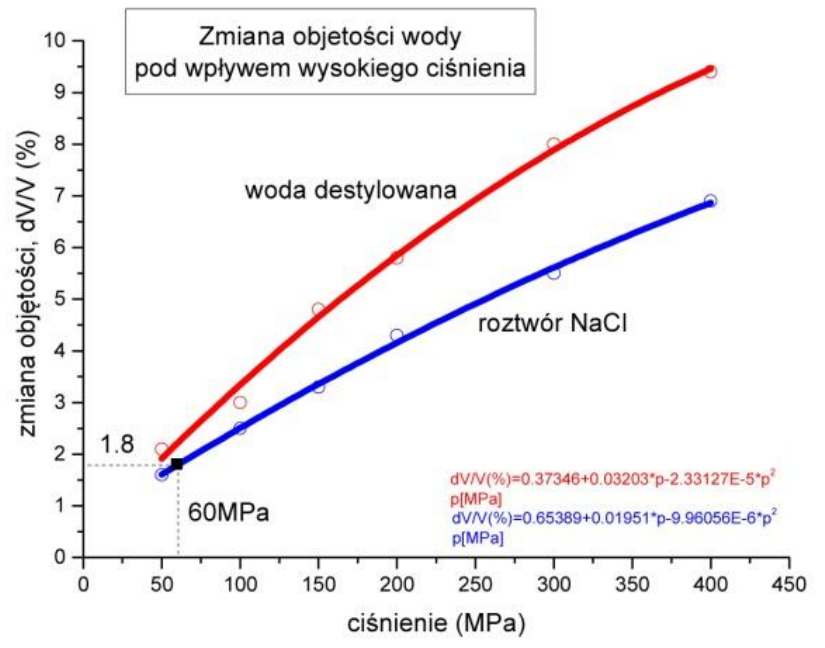

Rys. 21 Zmiany objętości wodnych roztworów pod wplywem wysokich ciśnień

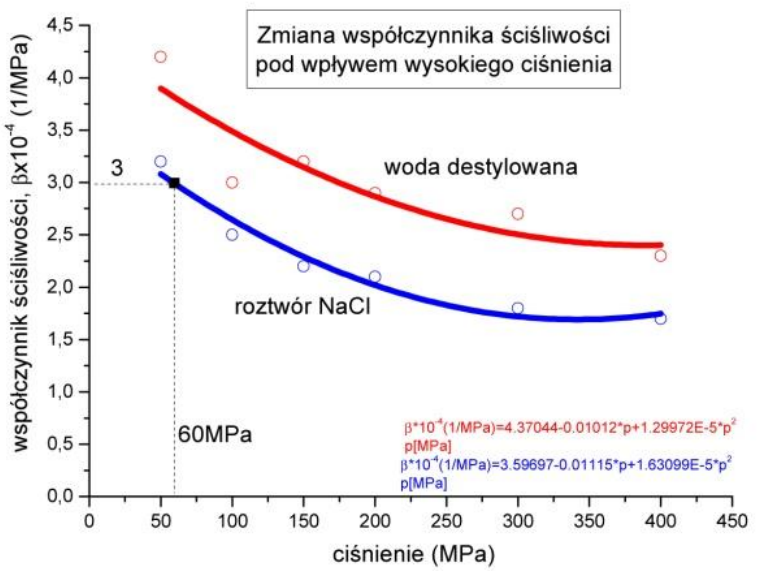

Rys. 22 Charakter zmian wspótczynnika ściśliwości $\beta$ wodnych roztworów pod wpływem działania wysokich ciśnień

Stanowisko składa się z części zasilającej oraz wysokociśnieniowej części roboczej. Część zasilającą stanowi istniejąca w Instytucie Wysokich Ciśnień Polskiej Akademii Nauk prasa składająca się z komory roboczej i multiplikatora ciśnienia (rys. 23). Wysokociśnieniowa część robocza do ciśnieniowania składa się z jednopłaszczowej komory do maksymalnego ciśnienia pracy $60 \mathrm{MPa}$ (rys. 24), zbudowana $\mathrm{z}$ przepony poliuretanowej, a także zbiornika poliuretanowego zawierającego medium do ciśnieniowania i komory stalowej. 
Testing the catastrophic recorder resistance against the impact of catastrophic... Badania odporności rejestratora katastroficznego na oddziaływanie czynników...

Stanowisko wyposażone jest w systemy kontroli, rejestracji i akwizycji danych w trakcie trwania procesu ciśnieniowania. Prasa zasilająca [8] umożliwia wygenerowanie

w komorze roboczej prasy ciśnienia hydrostatycznego do $1800 \mathrm{MPa}$ (rys. 23). Komora do ciśnieniowania pozwala na prowadzenie długookresowych badań ciśnieniowych w przedziale od 0 do 60 MPa. Po osiągnięciu wymaganego poziomu ciśnieniowania komorę do ciśnieniowania „odcina się” od prasy zasilającej zaworem ręcznym.

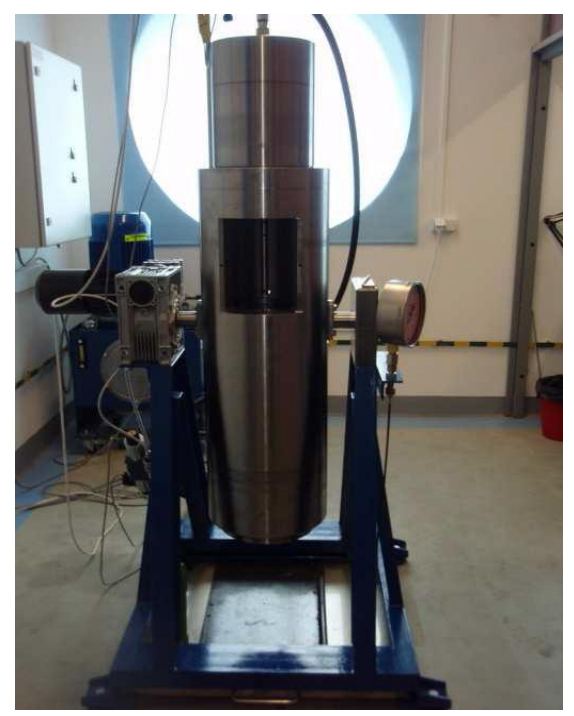

Rys. 23 Prasa z multiplikatorem ciśnienia [8]

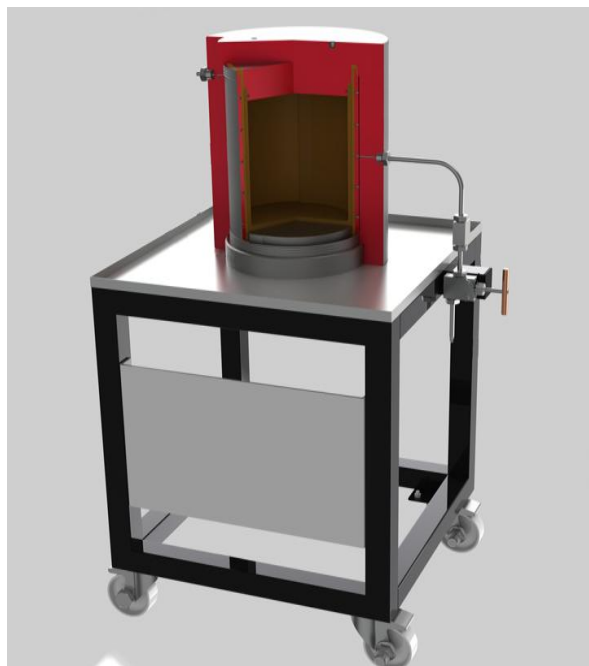

Rys. 24 Komora wysokociśnieniowa do hydrostatycznego ciśnieniowania do $60 \mathrm{MPa}$ [8] 
Zbigniew Jakielaszek, Grzegorz Kowaleczko, Andrzej J. Panas, Mirostaw Nowakowski

Projekt komory wykonanej ze stali 45HNMFA został poddany analizie matematycznej metodą elementów skończonych (MES) z wykorzystaniem programu Ansys Static Structural. Analizę przeprowadzono dla maksymalnego dopuszczalnego obciążenia równego $p_{H E}=60 \quad \mathrm{MPa} \quad \mathrm{z}$ uwzględnieniem współczynnika bezpieczeństwa $n=2$ [8]. Na rys. 25 przedstawiono analizę rozkładu naprężeń węzłowych w komorze.

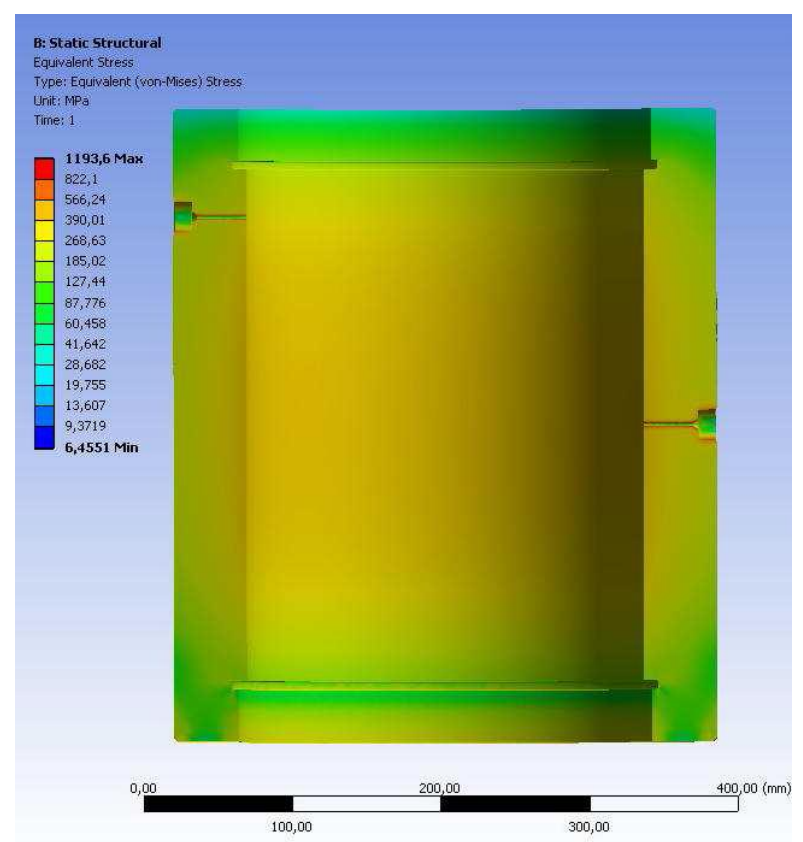

Rys. 25 Rozkład zredukowanych naprężeń węzłowych w komorze ciśnieniowej przy maksymalnym obciażeniu $p_{H E}=60 \mathrm{MPa}$ [8]

Stanowisko zostało poddane próbom eksploatacyjnym w celu sprawdzenia szczelności układu, stabilności ciśnieniowej w długim okresie oraz działania systemu rejestracji i akwizycji ciśnienia.

Próba była wykonana na obiekcie modelowym o objętości równej objętości rejestratora katastroficznego. Ciśnienie medium roboczego zostało podniesione do maksymalnego ciśnienia $60 \mathrm{MPa}$. Wyniki pomiarów ciśnienia w funkcji czasu zostały przedstawione na rys. 26. Wznoszące charakterystyki ilustrują wzrost ciśnienia natomiast jej wypłaszczenia przedstawiają przebiegi, w którym nastąpiło odcięcie komory roboczej prasy zasilającej za pomocą zaworu ręcznego i uzupełnienie $\mathrm{w}$ niej medium ciśnieniowego. W trakcie podnoszenia ciśnienia nie zaobserwowano żadnych nieszczelności w układzie. 
Testing the catastrophic recorder resistance against the impact of catastrophic... Badania odporności rejestratora katastroficznego na oddziaływanie czynników...

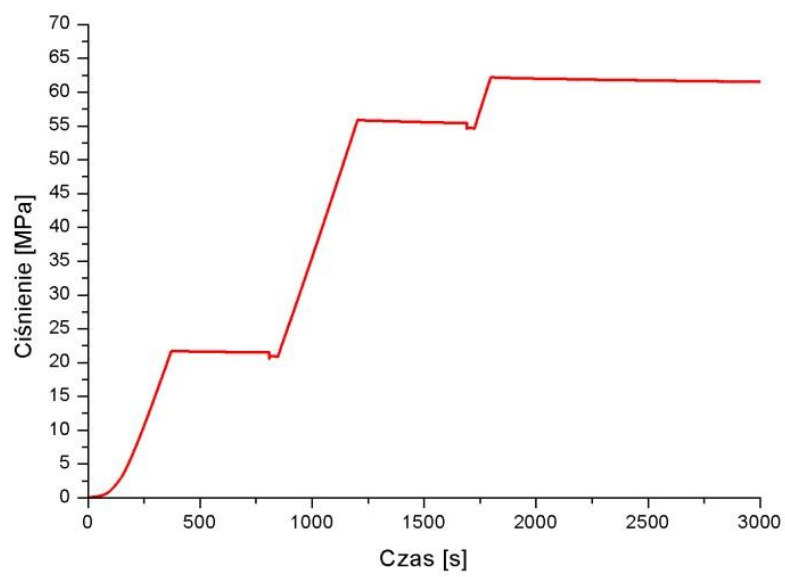

Rys. 26 Wykres ciśnienia w funkcji czasu podczas generowania ciśnienia $w$ komorze roboczej [8]

Ze względu na spadki ciśnienia związane ze stygnięciem medium podczas zatrzymania procesu sprężania, konieczne było wygenerowanie odpowiednio większego ciśnienia początkowego (rys. 27). W wyniku badań okazało się, że po krótkim czasie wyraźnego spadku przez kolejne 20 godzin ciśnienie malało nieznacznie. Podczas trwania próby uzyskano ciśnienie w komorze ciśnieniowej nie mniejsze niż $60 \mathrm{MPa}$ przez okres 24 godzin.
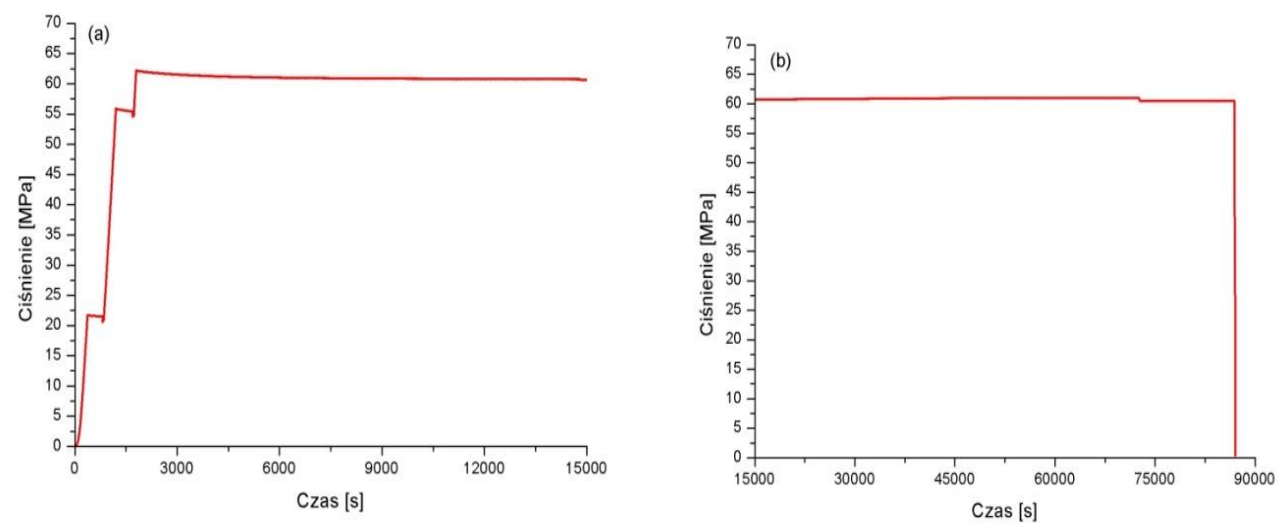

Rys. 27 Wykres ciśnienia w funkcji czasu dla petnego cyklu ciśnieniowania [8]

Cały proces prowadzenia prób był zdeterminowany zaleceniami zawartymi w normie EuroCAE ED-112. Badania przeprowadzono w Instytucie Wysokich Ciśnień PAN oraz w Instytucie Technicznym Wojsk Lotniczych. 
$\mathrm{Na}$ rys. 28 pokazano rejestrator katastroficzny umieszczony w komorze do ciśnieniowania.

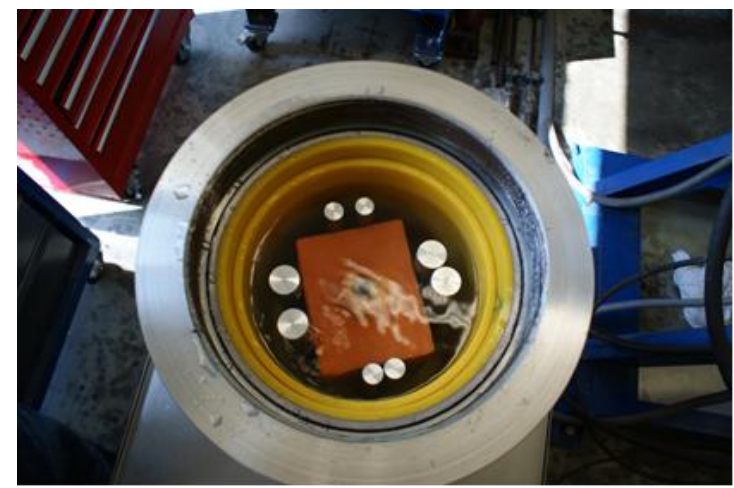

\section{Rys. 28 Otwarte stanowisko badawcze z zainstalowanym rejestratorem katastroficznym [8]}

$\mathrm{W}$ pamięci rejestratora katastroficznego zapisano dane testowe $\mathrm{w}$ formacie przeznaczonym dla śmigłowca Mi-17. Wykonano pięć kilkunastominutowych zapisów 8 parametrów, w tym dwóch analogowych, symulowanych przebiegiem sinusoidalnym o amplitudzie do $5 \mathrm{~V}$ DC i częstotliwościami ustawionymi w różnych zapisach na wartość $0,01,0,02$ i $0,03 \mathrm{~Hz}$. W tabeli 1 przedstawiono dane odczytane z kasety przed przystąpieniem do wykonania próby. Przyjęto, że wynik pozytywny badania to identyczność danych odczytanych $\mathrm{z}$ pamięci rejestratora katastroficznego przed i po zakończeniu badania. Dane odczytano za pomocą testera WTS-5 z zainstalowanym systemem deszyfracji Obiektywna Analiza Zapisu (OAZ) [9].

Tab. 1 Wartości parametrów diagnostycznych $w$ poszczególnych zapisach przed wykonaniem badania [9]

\begin{tabular}{|c|c|c|c|c|c|c|c|c|c|}
\hline $\begin{array}{c}\text { Nr } \\
\text { zapisu }\end{array}$ & $\begin{array}{c}\text { Data } \\
\text { zapisu }\end{array}$ & $\begin{array}{c}\text { Poczatek } \\
\text { zapisu }\end{array}$ & $\begin{array}{c}\text { Czas } \\
\text { trwania } \\
\text { zapisu }\end{array}$ & Diag & T & Kan.wz & NRID & Vpr & Hbar \\
\hline & D-M-R & h:m:s & h:m:s & {$[\mathrm{dz}]$} & {$[\mathrm{sek}]$} & {$[\mathrm{dz}]$} & {$[\mathrm{dz}]$} & {$[\mathrm{dz}]$} & {$[\mathrm{dz}]$} \\
\hline 1. & $22-04-14$ & $12: 09: 37$ & $00: 19: 11$ & 0 & $0 \div 1151$ & $2048 \div 2049$ & 696947 & $2049 \div 2050$ & $2557 \div 3581$ \\
\hline 2. & $22-04-14$ & $12: 29: 45$ & $00: 14: 57$ & 0 & $0 \div 897$ & $2048 \div 2049$ & 696947 & $2558 \div 3580$ & $2049 \div 2050$ \\
\hline 3. & $22-04-14$ & $12: 45: 34$ & $00: 14: 58$ & 0 & $0 \div 898$ & $2048 \div 2049$ & 696947 & $2049 \div 2050$ & $2558 \div 3581$ \\
\hline 4. & $22-04-14$ & $13: 01: 08$ & $00: 15: 02$ & 0 & $0 \div 902$ & $2048 \div 2049$ & 696947 & $2557 \div 3581$ & $2049 \div 2050$ \\
\hline 5. & $22-04-14$ & $13: 16: 54$ & $00: 14: 23$ & 0 & $0 \div 863$ & $2048 \div 2049$ & 696947 & $2049 \div 2050$ & $2557 \div 3581$ \\
\hline
\end{tabular}

Ponadto korzystając z przygotowanego zaplecza laboratoryjnego, dodatkowo przeprowadzono próbę wytrzymałości samego układu elektronicznego rejestratora katastroficznego na ciśnienie słupa wody morskiej o wysokości $6000 \mathrm{~m}$ w czasie 24 godzin.

Próbie hydrostatycznego ciśnieniowania została poddana jedynie elektronika w elastycznej masie kauczuku silikonowego. Charakterystyka ciśnienia działającego na pakiet elektroniki w funkcji czasu jest przedstawiona na rys. 29. Stan elementów elektronicznych jest przedstawiony na rys. 30 . 
Testing the catastrophic recorder resistance against the impact of catastrophic... Badania odporności rejestratora katastroficznego na oddziaływanie czynników...

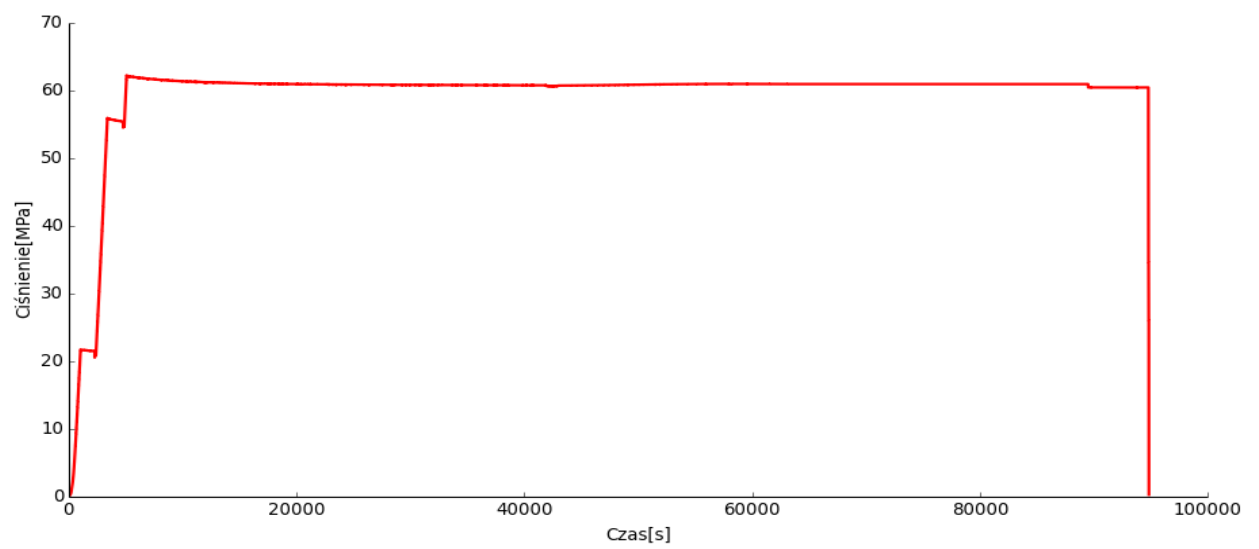

Rys. 29 Charakterystyka ciśnienia w funkcji czasu dla procesu ciśnieniowania układów elektronicznych rejestratora katastroficznego

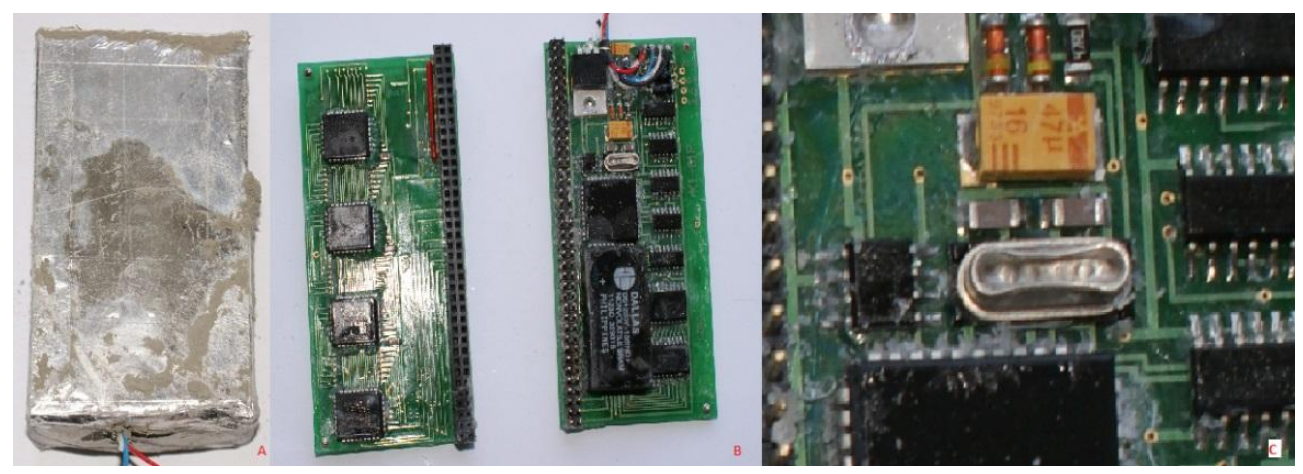

Rys. 30 Stan elementów elektronicznych po przeprowadzeniu próby ciśnieniowej

Dane po wykonaniu ciśnieniowania odczytano w taki sam sposób jak przed przystąpieniem do próby, za pomocą testera WTS-5 z zainstalowanym systemem deszyfracji OAZ. Stwierdzono pełną identyczność odczytanych parametrów, $\mathrm{w}$ porównaniu do odczytu dokonanego przed umieszczeniem rejestratora katastroficznego w komorze stanowiska badawczego. Wyniki odczytu pokazano w tabeli 2 .

Tab. 2 Wartości parametrów diagnostycznych $w$ poszczególnych zapisach po wykonaniu badania [9]

\begin{tabular}{|c|c|c|c|c|c|c|c|c|c|}
\hline $\begin{array}{c}\text { Nr } \\
\text { zapisu }\end{array}$ & $\begin{array}{c}\text { Data } \\
\text { zapisu }\end{array}$ & $\begin{array}{c}\text { Początek } \\
\text { zapisu }\end{array}$ & $\begin{array}{c}\text { Czas } \\
\text { trwania } \\
\text { zapisu }\end{array}$ & Diag & T & Kan.wz & NRID & Vpr & Hbar \\
\hline & D-M-R & h:m:s & h:m:s & {$[\mathrm{dz}]$} & {$[\mathrm{sek}]$} & {$[\mathrm{dz}]$} & {$[\mathrm{dz}]$} & {$[\mathrm{dz}]$} & {$[\mathrm{dz}]$} \\
\hline 1. & $22-04-14$ & $12: 09: 37$ & $00: 19: 11$ & 0 & $0 \div 1151$ & $2048 \div 2049$ & 696947 & $2049 \div 2050$ & $2557 \div 3581$ \\
\hline 2. & $22-04-14$ & $12: 29: 45$ & $00: 14: 57$ & 0 & $0 \div 897$ & $2048 \div 2049$ & 696947 & $2558 \div 3580$ & $2049 \div 2050$ \\
\hline 3. & $22-04-14$ & $12: 45: 34$ & $00: 14: 58$ & 0 & $0 \div 898$ & $2048 \div 2049$ & 696947 & $2049 \div 2050$ & $2558 \div 3581$ \\
\hline 4. & $22-04-14$ & $13: 01: 08$ & $00: 15: 02$ & 0 & $0 \div 902$ & $2048 \div 2049$ & 696947 & $2557 \div 3581$ & $2049 \div 2050$ \\
\hline 5. & $22-04-14$ & $13: 16: 54$ & $00: 14: 23$ & 0 & $0 \div 863$ & $2048 \div 2049$ & 696947 & $2049 \div 2050$ & $2557 \div 3581$ \\
\hline
\end{tabular}




\section{Badanie odporności rejestratora katastroficznego na oddziaływanie płynów agresywnych}

Badanie odporności rejestratora katastroficznego na oddziaływanie płynów agresywnych zgodnie $\mathrm{z}$ normą europejską EuroCAE ED-112 [2] i obronną NO-16-A200 [1] przeprowadza się poprzez zanurzenie rejestratora katastroficznego kolejno, na co najmniej 48 godzin w:

- paliwie lotniczym,

- oleju,

- mieszance hydraulicznej,

- środku gaśniczym.

Jako środek gaśniczy stosuje się:

- wodny roztwór glikolu,

- dwutlenek węgla,

- proszek gaśniczy,

- pianę gaśniczą.

W badaniach naziemnych rejestratora katastroficznego systemu rejestracji S2-3a wykorzystano paliwa lotnicze, oleje, ciecze hydrauliczne oraz środki gaśnicze użytkowane w lotnictwie Sił Zbrojnych RP.

Wynik badania uznaje się za pozytywny, jeżeli można odzyskać dane testowe zarejestrowane $\mathrm{w}$ pamięci rejestratora katastroficznego, poddanego badaniu odporności na oddziaływanie płynów agresywnych.

\section{Podsumowanie}

Rejestrator katastroficzny systemu rejestracji parametrów lotu S2-3a spełnia wymagania wytrzymałościowe normy obronnej NO-16-A200 (EuroCAE ED-112), tj. zabezpiecza zarejestrowaną $\mathrm{w}$ pamięci informację $\mathrm{w}$ przypadku:

- oddziaływania przeciążenia $3400 \mathrm{~g} \mathrm{w}$ czasie nie dłuższym niż $6,5 \mathrm{~ms}$;

- penetracji metalowym trzpieniem o średnicy $6,35 \mathrm{~mm}$, obciążonym masą 227 $\mathrm{kg}$ i spadającym z wysokości $3 \mathrm{~m}$;

- ściskania siłą statyczną $22,25 \mathrm{kN}$;

- oddziaływania temperatury $1100^{\circ} \mathrm{C} \mathrm{w}$ czasie dłuższym niż $30 \mathrm{~min}$;

- oddziaływania ciśnienia głębinowego wody morskiej $60 \mathrm{MPa}(6000 \mathrm{~m}$ poniżej poziomu wody) w czasie 24 godzin;

- oddziaływania płynów agresywnych.

\section{Literatura}

[1] Norma Obronna NO-16-A200:2006. Wojskowe statki powietrzne. Pokładowe rejestratory katastroficzne, Wymagania i badania. 2006.

[2] EuruCAE ED-112, Minimum operational performance specification for crash protected airbone recorder systems, Revision A September 1. 2013.

[3] Bakalarski J.: Opracowanie obudowy rejestratora parametrów lotu samolotu odpornej na graniczne warunki obciążeń mechanicznych i termicznych. Warszawa 1993, ITWL nr 10606/I.

[4] Lisiecki J.: Kaseta ochronna. PL 16969.

[5] Fiserova D.: Numerical analyses of buried mine explosions with emphasis on effect of soil properties on loading. Cranfield University, 2006.

[6] Lisiecki J., Błażejewicz T., Gmurczyk G.: Stanowisko do badania kasety rejestratora katastroficznego na działanie ognia. PL 65757. 
Testing the catastrophic recorder resistance against the impact of catastrophic... Badania odporności rejestratora katastroficznego na oddziatywanie czynników...

[7] Lisiecki J., Błażejewicz T.: Analiza materiałów PCM do zastosowania w kasecie ochronnej pod kątem temperatury przemiany. Sprawozdanie ITWL nr 140/31/2008, 2008

[8] Sprawozdanie z pracy pt. Stanowisko do hydrostatycznego ciśnieniowania rejestratora lotu $\mathrm{w}$ ciśnieniu $60 \mathrm{MPa} \mathrm{w}$ środowisku wody morskiej. IWC PAN 2015.

[9] Raport nr 6a/36/2015 z odczytu kaset ochronnych S2-3a-K i S2-3a-K/VCR poddanych działaniu ciśnienia wody morskiej, zgodnie z normą ED-112. ITWL 2015.
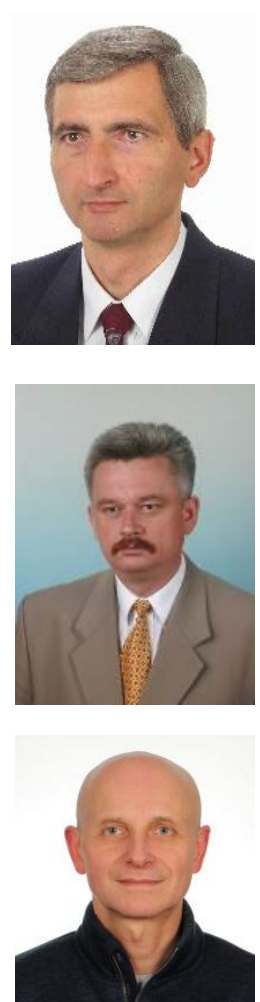

Dr hab. in. Mirostaw Nowakowski, prof. ITWL Kierownik Zakładu Samolotów i Śmigłowców Instytutu Technicznego Wojsk lotniczych. Specjalizuje sie $w$ badaniach statków powietrznych $w$ locie, $w$ tym badania kwalifikacyjne (państwowe), dopuszczajace do eksploatacji. Kieruje unikalnym $w$ kraju Laboratorium Badania Statków Powietrznych. Kierowat kilkudziesieccioma pracami naukowymi dla potrzeb Ministerstwa Obrony Narodowej. Rozwija prace badawcze $w$ obszarze bezpilotowych statków powietrznych (Udziat 25\%).

Mgr inz. Zbigniew Jakielaszek - absolwent Wojskowej Akademii Technicznej - specjalność osprzęt samolotów i śmigłowców. Major rezerwy. Stużyl w I PLM Mińsk Mazowiecki przy eksploatacji samolotów MiG-29 na stanowiskach dowódcy klucza osprzętu eskadry oraz inżyniera osprzętu putku. Obecnie $w$ ITWL na stanowisku kierownika pracowni aparatury pomiarowej do badań $w$ locie SP. Wspóttwórca systemów pomiarowo-rejestrujacych wykorzystywanych podczas badań wielu typów samolotów (Udziat 25\%).

Prof. dr hab. inz. Andrzej J. Panas. Ukończyt studia w zakresie fizyki technicznej w Wojskowej Akademii Technicznej (1983) i matematyki stosowanej na Uniwersytecie Warszawskim (1987). Zatrudniony $w$ Wojskowej Akademii Technicznej od 1984 r., od 2008 r. pracownik naukowo-badawczy Instytutu Technicznego Wojsk Lotniczych. Stopień doktora $w$ dziedzinie nauk technicznych uzyskat w 1989 r., doktora habilitowanego w 1999 r., a tytul profesora w 2009 r. Obszary działalności naukowej to termodynamika stosowana, właściwości cieplnofizyczne substancji, modelowanie analityczne i numeryczne procesów wymiany ciepła i masy, metrologia procesów cieplnych. Autor bądź współautor 4 monografii oraz ponad 120. artykułów i ponad 50. komunikatów naukowych (Udziat 25\%).

Prof. dr hab. inz. Grzegorz Kowaleczko jest absolwentem Wojskowej Akademii Technicznej. Obszar zainteresowań naukowych to mechanika lotu stałopłatów $i$ wirnikowych statków powietrznych, a $w$ tym $w$ szczególności modelowanie dynamiki lotu, wplyw uszkodzeń struktur nośnych na lot, lot $w$ warunkach oblodzenia, opis matematyczny turbulencji atmosfery $i$ ich wplyw na lot. Inne obszary działalności naukowej symulacje dotyczace zrzutu bomb oraz dynamiki lotu pocisków i rakiet, paralotni i spadochronów (Udziat 25\%). 